



\section{Meerkosten biodiversiteitsmaatregelen voor melkvee- en akkerbouwbedrijven}

Alfons Beldman ${ }^{1}$, Nico Polman ${ }^{1}$, Harry Kager ${ }^{2}$, Gerben Doornewaard ${ }^{1}$, Auke Greijdanus ${ }^{1}$, Henri Prins ${ }^{1}$, Marijke Dijkshoorn ${ }^{1}$, Judy Koppenjan ${ }^{2}$

1 Wageningen Economic Research

2 Schuttelaar \& Partners

Dit onderzoek is uitgevoerd door Wageningen Economic Research in opdracht van het Deltaplan Biodiversiteitsherstel in het kader van het beleidsondersteunend onderzoeksthema 'Natuurinclusief Nederland' (projectnummer BO-43-023.01-029). Het is gefinancierd door het Deltaplan Biodiversiteitsherstel en het ministerie van Landbouw, Natuur en Voedselkwaliteit.

Wageningen Economic Research

Wageningen, oktober 2019

RAPPORT

2019-105

ISBN 978-94-6395-143-2 
Alfons Beldman, Nico Polman, Harry Kager, Gerben Doornewaard, Auke Greijdanus, Henri Prins, Marijke Dijkshoorn, Judy Koppenjan, 2019. Meerkosten biodiversiteitsmaatregelen voor melkvee- en akkerbouwbedrijven. Wageningen, Wageningen Economic Research, Rapport 2019-105. 52 blz.; 4 fig.; 12 tab.; 26 ref.

Het doel van dit onderzoek is om inzicht te geven in de meerkosten voor melkvee- en akkerbouwbedrijven van biodiversiteitsmaatregelen op basis van een integraal betere score op indicatoren uit de biodiversiteitsmonitor. De kosten voor intensieve melkveebedrijven, extensieve melkveebedrijven en bedrijven op veen zijn respectievelijk $€ 1,95, € 2,18$ en $€ 3,08$ per honderd $\mathrm{kg}$ melk. Gewogen over deze drie bedrijfstypen in de melkveehouderij zijn de meerkosten $€ 2,21$ per honderd kg melk ofwel $€ 417$ per hectare. De geraamde meerkosten voor akkerbouwbedrijven op klei met een bouwplan met consumptieaardappelen en voor akkerbouwbedrijven op zand met een bouwplan met zetmeelaardappelen zijn respectievelijk $€ 324$ en $€ 185$ per hectare. Voor zowel de melkveehouderij als de akkerbouw is een breed pakket aan maatregelen nodig om tot een betere score te komen.

The aim of this study is to provide insight into the additional costs of biodiversity measures for dairy farms and arable farms on the basis of an integral better score on indicators from the biodiversity monitor. The costs for intensive dairy farms, extensive dairy farms and farms on peat are $€ 1.95$, $€ 2.18$ and $€ 3.08$ per $100 \mathrm{~kg}$ of milk respectively. Weighted over the three types of farms in the dairy farming sector, the additional costs are $€ 2.21$ per $100 \mathrm{~kg}$ of milk and $€ 417$ per hectare. The estimated additional costs for arable farms on clay with a cultivation plan with potatoes for consumption or on sand with a cultivation plan with potatoes for starch are 324 and 185 per hectare respectively. Both dairy farming and arable farming require a wide range of measures to achieve a better score.

Trefwoorden: biodiversiteit, biodiversiteitsmonitor, meerkosten, akkerbouw, melkveehouderij

Dit rapport is gratis te downloaden op https://doi.org/10.18174/501680 of op www.wur. nl/economicresearch (onder Wageningen Economic Research publicaties).

(C) 2019 Wageningen Economic Research

Postbus 29703, 2502 LS Den Haag, T 07033583 30, E communications.ssg@wur.nl, www.wur.nl/economic-research. Wageningen Economic Research is onderdeel van Wageningen University \& Research.

\section{(cc) BY-NC}

Dit werk valt onder een Creative Commons Naamsvermelding-Niet Commercieel 4.0 Internationaallicentie.

(C) Wageningen Economic Research, onderdeel van Stichting Wageningen Research, 2019 De gebruiker mag het werk kopiëren, verspreiden en doorgeven en afgeleide werken maken. Materiaal van derden waarvan in het werk gebruik is gemaakt en waarop intellectuele eigendomsrechten berusten, mogen niet zonder voorafgaande toestemming van derden gebruikt worden. De gebruiker dient bij het werk de door de maker of de licentiegever aangegeven naam te vermelden, maar niet zodanig dat de indruk gewekt wordt dat zij daarmee instemmen met het werk van de gebruiker of het gebruik van het werk. De gebruiker mag het werk niet voor commerciële doeleinden gebruiken.

Wageningen Economic Research aanvaardt geen aansprakelijkheid voor eventuele schade voortvloeiend uit het gebruik van de resultaten van dit onderzoek of de toepassing van de adviezen.

Wageningen Economic Research is ISO 9001:2015 gecertificeerd.

Wageningen Economic Research Rapport 2019-105 | Projectcode 2282300397

Foto omslag: Shutterstock 


\section{Inhoud}

$\begin{array}{ll}\text { Woord vooraf } & 5\end{array}$

$\begin{array}{ll}\text { Samenvatting } & 6\end{array}$

S.1 Belangrijkste uitkomsten $\quad 6$

S.2 Overige uitkomsten $\quad 6$

$\begin{array}{lll}\text { S.3 Methode } & 6\end{array}$

$\begin{array}{ll}\text { Summary } & 8\end{array}$

$\begin{array}{lll}\text { S.1 Important outcomes } & 8\end{array}$

S.2 Complementary outcomes $\quad 8$

S.3 Methodology 18

$\begin{array}{ll}1 & \text { Inleiding }\end{array}$

2 Methode $r$

2.1 Aanpak en fasering 11

2.2 Uitgangspunten voor het onderzoek $\quad 12$

2.3 Aanpak vaststellen van bedrijfstypen en huidige niveau bedrijfsvoering 14

2.4 Aanpak definiëren van maatregelenpakketten 18

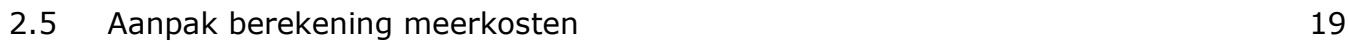

$\begin{array}{llr}3 & \text { Resultaten } & \mathbf{2 1}\end{array}$

$\begin{array}{lll}3.1 & \text { Bedrijfstypen en niveau A en B } & 21\end{array}$

3.1.1 Bedrijfstypen en indicatoren melkvee $\quad 21$

$\begin{array}{ll}3.1 .2 \text { Bedrijfstypen en indicatoren akkerbouw } & 22\end{array}$

3.2 Maatregelenpakketten $\quad 23$

3.2.1 Maatregelenpakketten melkveebedrijven $\quad 24$

3.2.2 Maatregelenpakketten akkerbouwbedrijven $\quad 29$

3.3 Kosten van de maatregelenpakketten 31

$\begin{array}{ll}\text { 3.3.1 Kosten voor melkveebedrijven } & 31\end{array}$

$\begin{array}{ll}\text { 3.3.2 Kosten voor akkerbouwbedrijven } & 34\end{array}$

4 Conclusies, discussie en aanbevelingen $\quad 37$

$\begin{array}{lll}4.1 & \text { Conclusies } & 37\end{array}$

$\begin{array}{lll}4.2 & \text { Discussie } & 37\end{array}$

$\begin{array}{lll}4.3 & \text { Aanbevelingen } & 39\end{array}$

$\begin{array}{ll}\text { Literatuur en websites } & 41\end{array}$

Bijlage 1 Typen melkveebedrijven kenmerken bedrijf en bedrijfsvoering 43

Bijlage 2 Literatuurbronnen longlist biodiversiteitsmaatregelen $\quad 44$

$\begin{array}{ll}\text { Bijlage } 3 \text { Deelnemers expertworkshop } & 45\end{array}$

Bijlage 4 Resultaat expertworkshop: prioriteiten van maatregelen 46 



\section{Woord vooraf}

In het Deltaplan Biodiversiteitsherstel werkt een brede maatschappelijke coalitie samen om tot herstel van de biodiversiteit te komen. Kern van de aanpak van het Deltaplan is dat verschillende partijen in staat zijn om grondgebruikers - zoals natuurbeheerders, boeren, overheden en particulieren - te stimuleren en te waarderen voor hun prestaties die bijdragen aan herstel van biodiversiteit.

De werkroute landbouw van het Deltaplan, bestaande uit een vertegenwoordiging van een deel van de partijen in de coalitie, heeft Wageningen Economic Research gevraagd nader inzicht te geven in de meerkosten van biodiversiteitsmaatregelen voor melkvee- en akkerbouwbedrijven. Het onderzoek is mede gefinancierd vanuit het ministerie van Landbouw, Natuur en Voedselkwaliteit. De werkroute landbouw die optrad als begeleidingsgroep voor het onderzoek bestond uit de volgende personen: Ben Haarman (LTO, voorzitter), Bas Rüter (Rabobank), Jeen Nijboer (Rabobank), Hedwig Boerrigter (Stichting Veldleeuwerik), Inge van Schie Rameijer (Duurzame Zuivelketen), Alex Datema (BoerenNatuur), Sieto van Houten (Agrifirm), Raymond Klaassen (RUG), Natasja Oerlemans (en Jacomijn Pluimers, Wereld Natuur Fonds), Petra Souwerbren (de Natuur en Milieufederaties) en Willemien van de Kandelaar (LTO). Aanvullend zijn Arne Meeter en Martijn van der Heide namens het ministerie van LNV aangesloten bij de begeleidingscommissie.

In het onderzoek is een brede groep van experts ingezet om tot een prioritering van maatregelen te komen die genomen kunnen worden. De samengestelde maatregelenpakketten zijn gereviewd door experts van buiten het projectteam.

Ik wil graag alle experts danken voor hun waardevolle bijdrage aan het project en in het bijzonder de leden van de werkroute landbouw voor de begeleiding van het onderzoek en de waardevolle feedback op de verschillende stappen in het project.

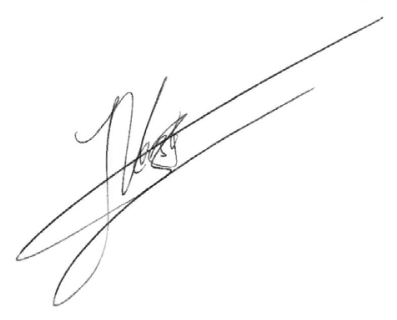

Prof.dr.ir. J.G.A.J. (Jack) van der Vorst Algemeen Directeur Social Sciences Group (SSG) Wageningen University \& Research 


\section{Samenvatting}

\section{S.1 Belangrijkste uitkomsten}

Om voor bestaande bedrijven tot een integraal betere score op indicatoren voor biodiversiteit (KPI's) te komen, is voor zowel de melkveehouderij als de akkerbouw een breed pakket aan maatregelen nodig. Dit brede pakket is nodig om uiteindelijk op alle KPI's tot een betere score te komen. De betere score is gebaseerd op de $30 \%$ best presterende bedrijven (paragraaf 3.2 ).

De jaarlijkse kosten om integraal beter te scoren op indicatoren uit de biodiversiteitsmonitor zijn voor drie melkveebedrijfstypen berekend en bedragen voor intensieve melkveebedrijven, extensieve melkveebedrijven en bedrijven op veen respectievelijk $€ 1,95, € 2,18$ en $€ 3,08$ per honderd $\mathrm{kg}$ melk. Gewogen over de drie bedrijfstypen in de melkveehouderij zijn de meerkosten $€ 2,21$ per honderd $\mathrm{kg}$ melk en $€ 417$ per hectare (paragraaf 3.3.1). Voor de akkerbouw zijn de meerkosten voor twee bedrijfstypen berekend. De geraamde meerkosten voor akkerbouwbedrijven op klei met een bouwplan met consumptieaardappelen en voor akkerbouwbedrijven op zand met een bouwplan met zetmeelaardappelen zijn respectievelijk $€ 324$ en $€ 185$ per hectare per jaar (paragraaf 3.3.2). Ter vergelijking: over de afgelopen 5 jaar was het gemiddelde inkomen uit bedrijf op melkveebedrijven 1000 euro/ha en op akkerbouwbedrijven 800 euro/ha (Bron: Bedrijven Informatie Net van Wageningen Economic Research. De berekende meerkosten zijn gebaseerd op maatregelen die nodig zijn om van het niveau van de $70 \%$ slechtst presterende bedrijven op het niveau van de $30 \%$ best presterende bedrijven te komen.

Er is aanvullend onderzoek nodig om het door het Deltaplan geschetste droombeeld (website Deltaplan) ten aanzien van biodiversiteitsprestatie op melkvee- en akkerbouwbedrijven concreet te maken en vervolgens ook de meerkosten daarvan in beeld te kunnen brengen (hoofdstuk 4).

\section{S.2 Overige uitkomsten}

Voor melkveebedrijven hebben de maatregelen om integraal beter te scoren op biodiversiteit betrekking op het bouwplan (een groter aandeel gras als vervanger van mais en een groter aandeel blijvend grasland), de directe natuurmaatregelen, de aanpassingen in de bedrijfsvoering (meer beweiding, minder kunstmestbemesting, optimalisatie bemesting, optimalisatie voeding, levensduurverlenging, werken met lichtere machines) en de maatregelen die gericht zijn op het klimaat (zonnepanelen en gebruik van krachtvoer met een lagere footprint) (paragraaf 3.2.1).

Voor akkerbouwbedrijven hebben de maatregelen met name betrekking op de bodem. Het meer toepassen van niet-kerende grondbewerking, het aanvoeren of vasthouden van extra organische stof en het gebruik van lichtere machines in combinatie met een bouwplan met meer rustgewassen moet tot een betere bodemkwaliteit leiden. Daarnaast wordt de bemesting geoptimaliseerd en wordt het gebruik van gewasbeschermingsmiddelen gereduceerd. De natuurbeheermaatregelen worden ingevuld door bloeiende akkerranden en ruige vegetatie in overhoekjes (paragraaf 3.2.2).

\section{S.3 Methode}

Het doel van dit onderzoek is gericht op de vraag in welke mate de kostprijs van de brede groep melkvee- en akkerbouwbedrijven stijgt wanneer deze maatregelen nemen die resulteren in een betere biodiversiteit, gemeten in een integraal hoge(re) score op de KPI's uit de biodiversiteitsmonitor. Het te realiseren hogere niveau dient hierbij gebaseerd te zijn op het niveau dat de beter presterende bedrijven in de praktijk nu al realiseren. 
In dit onderzoek zijn de volgende stappen op hoofdlijnen uitgevoerd, mede ingegeven door een korte doorlooptijd:

- Het kiezen van bedrijfstypen: het onderzoek is uitgevoerd voor drie bedrijfstypen in de melkveehouderij en twee bedrijfstypen in de akkerbouw omdat de verwachting is dat de te nemen maatregelen en de effecten per bedrijfstype verschillen (paragraaf 2.3);

- Het vaststellen van de uitgangsituatie en het gewenste niveau van biodiversiteitsindicatoren. Voor de melkveebedrijven zijn de indicatoren uit de Biodiversiteitsmonitor Melkveehouderij gebruikt voor het vaststellen van het biodiversiteitsniveau. Voor de akkerbouw is gewerkt met KPI's die in een expert workshop zijn vastgesteld. Binnen elk bedrijfstype is op basis van het Bedrijveninformatienet vervolgens gekeken naar de gemiddelde score op de individuele KPI's van de $30 \%$ best scorende bedrijven en het niveau van de overige $70 \%$ van de bedrijven. Het niveau van de overige $70 \%$ wordt in dit rapport verder aangeduid als niveau A (uitgangsniveau), het niveau van de $30 \%$ best presterende bedrijven als niveau B (paragraaf 2.3);

- Het samenstellen van maatregelenpakketten: vertrekpunt was een longlist op basis van bestaande literatuur. Vervolgens zijn de maatregelen geprioriteerd en nader geconcretiseerd met behulp van een expertworkshop. De opdracht in de expert workshop was om een maatregelenpakket samen te stellen per bedrijfstype om voor de indicatoren van niveau A naar niveau $B$ te komen. Het projectteam heeft de maatregelenpakketten concreet en kwantitatief ingevuld. Dit concrete pakket is gereviewd door deskundigen (paragraaf 2.4);

- Het doorrekenen van de effecten van de maatregelen op de kostprijs. De meerkosten zijn per maatregel per bedrijfstype berekend. Eventuele investeringen zijn op basis van afschrijvingen en rentekosten omgerekend naar jaarkosten. In de berekeningen is rekening gehouden met eventuele besparingen en extra opbrengsten. Effecten van maatregelen zijn waar mogelijk afgeleid van gegevens uit het Informatienet. Daarnaast is gebruikgemaakt van eerder uitgevoerd onderzoek en zijn experts geraadpleegd. De meerkosten worden conform de vraag van de opdrachtgever uitgedrukt per honderd kg melk voor de melkveehouderij en per hectare voor de akkerbouw (paragraaf 2.5);

- Het trekken van conclusies, discussie en het geven van aanbevelingen. 


\section{Summary}

\section{S.1 Important outcomes}

In order to achieve an overall better score for biodiversity indicators (KPIs), a broad package of measures is needed for both dairy farms and arable farms. The better score is based on the $30 \%$ best performing farms (Section 3.2).

The yearly costs of an integral better score on indicators from the biodiversity monitor have been calculated for three dairy farm types. The costs for intensive dairy farms, extensive dairy farms and farms on peat are $€ 1.95, € 2.18$ and $€ 3.08$ per $100 \mathrm{~kg}$ of milk respectively. Weighted over the three types of farms in the dairy farming sector, the additional costs are $€ 2.21$ per $100 \mathrm{~kg}$ of milk and $€ 417$ per hectare (Section 3.3.1). For arable farming the costs have been calculated for two farm types. The estimated additional costs for arable farms on clay with a cultivation plan with potatoes for consumption or on sand with a cultivation plan with potatoes for starch are 324 and 185 per hectare respectively (Section 3.3.2). To compare: the average income over de last 5 years was about $€ 1000$ per ha for dairy farms and $€ 800$ /ha for arable farms. The extra costs are based on packages of measures that are required to achieve the level of the $30 \%$ best performing farms for the remaining $70 \%$ of the farms.

Additional research is needed to make the 'dreaml picture' as descibed by the Delta Plan (website Delta Plan) of biodiversity performance on dairy farms and arable farms concrete and then to identify the additional costs involved (Chapter 4).

\section{S.2 Complementary outcomes}

In the case of dairy farms, the measures relate to the crop rotation plan (a larger proportion of grass as a replacement for maize and a larger proportion of permanent pasture), direct nature conservation measures, operational changes (more grazing, lower fertiliser application, optimisation of fertiliser, optimisation of nutrition, extension of life span of dairy cows, working with lighter machines) and measures aimed at the climate (installing solar panels and the use of concentrate feed with a lower carbon footprint) (Section 3.2.1).

In the case of arable farms, the measures relate mainly to the soil. More non-returnable tillage, supplying or retaining extra organic matter, using lighter machines in combination with a crop rotation plan with more rest crops must lead to better soil quality. Fertilisation is also optimised and the use of crop protection agents is reduced. The nature management measures are implemented by means of flowering field margins and rough vegetation in overhangs (Section 3.2.2).

\section{S.3 Methodology}

The aim of the research was to assess the increase in costs of production of dairy and arable farms as a result of measures that have to be taken in order to achieve a higher level of biodiversity. A higher level of biodiversity in this study is measured as a higher integral score of the KPIs from the biodiversity monitor. The higher level that has be achieved is based on the level that is achieved by the better performing farms. 
In this study, the following main steps were carried out:

- Choice of farm types: The study was carried out for 3 types of farms in the dairy farming sector and 2 types of farms in the arable farming sector because it is expected that the measures to be taken and the effects will differ per farm type (Section 2.3).

- Determining the starting level and the level to be achieved. For the dairy farm types the indicators from the Biodiversity Monitor Dairy have been used to assess the level of biodiversity. For the arable farms the indicators have been chosen in an expert workshop. Farm data was used from the Farm Accountancy Data Network (FADN). Within each farm type the average score on these KPIs has been assessed based on the $30 \%$ best performing farms and compared with the average score of the remaining $70 \%$ of the farms. The level of the $70 \%$ group is referred to as level $A$. The level of the best performing farms is referred to as level B (Section 2.3).

- Compilation of packages of measures. The starting point was a long list based on existing literature, after which the measures were prioritised and further specified by means of an expert workshop. The assignment for the experts was to compile a package of measures that would bring the performance for each farm type from level A to level B. The project team completed the measure packages in concrete and quantitative terms. This concrete package was reviewed by experts (Section 2.4).

- Calculating the effects of the measures on the cost price. The extra costs have calculated per measure and per farm type. Investments have been transformed in yearly costs based on depreciation and interest costs. Impact of measures have been based on FADN data were possible. The extra costs have been calculated in $€$ per $100 \mathrm{~kg}$ milk for dairy farms and in $€$ per hectare for the arable farms (Section 2.5). 


\section{$1 \quad$ Inleiding}

Samen biodiversiteitsverlies ombuigen naar biodiversiteitsherstel is het doel van het Deltaplan Biodiversiteitsherstel. Door prestaties eenduidig meetbaar te maken ziet het Deltaplan mogelijkheden voor het stapelen van beloning en het optellen van deze prestaties tot echte biodiversiteitswinst. Kern van de aanpak van het Deltaplan is dat verschillende partijen in staat zijn om grondgebruikers - zoals natuurbeheerders, boeren, overheden en particulieren - te stimuleren en te waarderen voor hun prestaties die bijdragen aan herstel van biodiversiteit (website Deltaplan Biodiversiteitsherstel).

Meetbare prestaties vormen dus het vertrekpunt voor de coalitie en daarom ook voor dit onderzoek. Een biodiversiteitsmonitor, die voor de melkveehouderij reeds is ontwikkeld, is voor het Deltaplan en voor dit onderzoek het vertrekpunt. Voor de akkerbouw is een soortgelijke monitor in ontwikkeling en zijn voor dit project met behulp van experts KPI's gekozen. De Werkroute landbouw van de coalitie Deltaplan Biodiversiteitsherstel heeft Wageningen Economic Research gevraagd inzicht te geven in het effect van biodiversiteitsmaatregelen op de kostprijs van primaire bedrijven. Het gaat hierbij om inzicht in de kosten van maatregelen die de grote groep reguliere bedrijven zouden moeten nemen om op een hoger niveau voor een aantal biodiversiteitsindicatoren te komen. Dit hogere niveau moet nu al haalbaar zijn en wordt daarom afgeleid van huidige praktijkgegevens van praktijkbedrijven die nu al beter presteren.

Het doel van dit onderzoek is gericht op vraag in welke mate de kostprijs van de brede groep melkvee- en akkerbouwbedrijven stijgt wanneer deze maatregelen nemen die resulteren in een betere biodiversiteit, gemeten in een integraal hoge(re) score op de KPI's uit de biodiversiteitsmonitor. Het te realiseren hogere niveau dient hierbij gebaseerd te zijn op het niveau dat de best presterende bedrijven in de praktijk nu al realiseren. De concrete vraag van de Werkroute landbouw was om de meerkosten per kilogram melk voor melkveebedrijven en per hectare voor akkerbouwbedrijven te berekenen. De nadruk in de opdracht lag het meest op de melkveehouderij, voor de akkerbouw is een eerste verkenning toegezegd, mede omdat er nog geen definitieve sets van KPI's beschikbaar is.

Voor het Deltaplan is dit niveau niet het droombeeld, maar wordt het vooral gezien als een eerste belangrijke stap richting een landbouw die een minder negatieve impact heeft op de biodiversiteit in de omgeving en zelf ook een directe bijdrage levert aan meer behoud en ontwikkeling van biodiversiteit. Het droombeeld van het Deltaplan (website Deltaplan) gaat duidelijk nog een stap verder. Om ook voor dat hogere ambitieniveau de meerkosten in beeld te brengen, is echter eerst een nadere concretisering nodig. 


\section{$2 \quad$ Methode}

\subsection{Aanpak en fasering}

Het doel van dit onderzoek is gericht op vraag in welke mate de kostprijs van de brede groep melkvee- en akkerbouwbedrijven stijgt wanneer deze maatregelen nemen die resulteren in een betere biodiversiteit, gemeten in een integraal hoge(re) score op de KPI's uit de biodiversiteitsmonitor. Het te realiseren hogere niveau dient hierbij gebaseerd te zijn op het niveau dat de best presterende bedrijven in de praktijk nu al realiseren.

De onderzoeksaanpak bestond uit de volgende vijf stappen:

1. Het vaststellen van de algemene uitgangspunten voor het onderzoek (paragraaf 2.2);

2. Het vaststellen van bedrijfstypen en het huidig niveau van de bedrijfsvoering (methode in paragraaf 2.3 en resultaten in paragraaf 3.1 ) in twee substappen:

a. Het vaststellen van de bedrijfstypen voor melkvee en akkerbouw waar de meerkosten voor berekend worden;

b. Het vaststellen van het te realiseren hogere niveau (niveau $B$ ) en uitgangssituatie (niveau $A$ ) op basis van praktijkgegevens. Niveau B wordt daarbij gebaseerd op de gegevens van de $30 \%$ best presterende bedrijven uit het Bedrijveninformatienet. Voor niveau A worden de gegevens van de overige $70 \%$ van de bedrijven gebruikt. Niveau A weerspiegelt daarmee de huidige situatie op een brede groep bedrijven die maatregelen moeten gaan nemen.

3. Het definiëren van maatregelenpakketten per bedrijfstype (methode in paragraaf 2.4 en resultaten in paragraaf 3.2) in drie substappen:

a. Het opstellen van een gemeenschappelijke longlist op basis van bestaande literatuur voor alle bedrijfstypen gezamenlijk;

b. Het prioriteren van de maatregelen per bedrijfstype met behulp van een expertworkshop; en

c. Het reviewen van het maatregelenpakket door deskundigen;

4. Het doorrekenen van de effecten van de maatregelen op de kostprijs. De meerkosten zijn per maatregel per bedrijfstype berekend op basis van de gemiddelde situatie (gebaseerd op het informatienet) van de betreffende groep. Eventuele investeringen zijn op basis van afschrijvingen en rentekosten omgerekend naar jaarkosten. In de berekeningen is rekening gehouden met eventuele besparingen. Effecten van maatregelen zijn waar mogelijk afgeleid van gegevens uit het Informatienet. Daarnaast is gebruikgemaakt van eerder uitgevoerd onderzoek en zijn experts geraadpleegd. Voor melkvee zijn de kosten toegerekend aan de productie van melk, voor akkerbouw zijn de meerkosten per hectare berekend (methode in paragraaf 2.5, resultaten in paragraaf 3.3);

5. Het trekken van conclusies, discussie en het geven aanbevelingen (hoofdstuk 4).

Het onderzoek is uitgevoerd in de periode juni tot augustus 2019 en was beperkt in omvang. Vanwege de beperkte omvang en korte doorlooptijd moesten er keuzes worden gemaakt en kon niet alles in detail worden uitgezocht. De opdracht was primair gericht op de melkveehouderij, voor de akkerbouw was de opzet om een eerste verkenning te doen, mede omdat er nog geen definitieve set van KPI's beschikbaar is voor biodiversiteit. 


\subsection{Uitgangspunten voor het onderzoek}

In deze paragraaf beschrijven we de uitgangspunten voor het onderzoek.

1. Voor de melkveehouderij vormen de KPI's van de Biodiversiteitsmonitor Melkveehouderij het vertrekpunt. De biodiversiteitsmonitor (Laarhoven et al., 2018) ${ }^{1}$ werkt met een integrale set van zeven kritische presentatie-indicatoren (KPI's):

- Percentage blijvend grasland;

- Percentage eiwit van eigen bedrijf/uit eigen regio $(<20 \mathrm{~km})$;

- Stikstofbodemoverschot (kg per ha);

- Emissie van ammoniak (kg per ha);

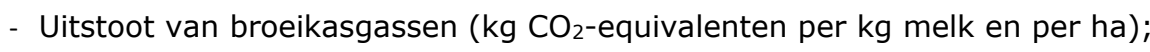

- Percentage kruidenrijk grasland; en

- Percentage natuur en landschap (percentage beheerd land met beheerscontract).

2. De set KPI's voor de akkerbouw is met name gebaseerd op input van de geraadpleegde experts en de projectgroep die aan de KPI's voor akkerbouw werkt. De gebruikte KPI's zijn:

- Percentage rustgewassen;

- Percentage groenbemester;

- Organischestofbalans;

- N-overschot (kg per ha);

- Agrarisch natuurbeheer ( $€$ per ha);

- Gebruik gewasbeschermingsmiddelen (kg actieve stof per ha).

De KPI's zijn afgestemd met de projectgroep die zich bezighoudt met de ontwikkeling van de Biodiversiteitsmonitor Akkerbouw op het moment dat deze groep zich in een opstartfase bevond. De set KPI's die in dit onderzoek wordt gebruikt, is daarmee op geen enkele wijze richtinggevend voor het eindresultaat van de Biodiversiteitsmonitor Akkerbouw.

3. In dit onderzoek wordt gekeken hoe bedrijven integraal scoren op de combinatie van KPI's door de afzonderlijke scores gewogen op te tellen. Elke KPI heeft de weging 1, met uitzondering van de twee $\mathrm{CO}_{2}$-gerelateerde KPI's in de melkveehouderij, die elk voor $1 / 2$ meetellen.

4. Binnen het onderzoek is onderscheid gemaakt tussen een aantal bedrijfstypen om rekening te houden met de diversiteit. Vertrekpunt van de opdracht was om het onderzoek uit te voeren voor drie bedrijfstypen voor de melkveehouderij en voor twee bedrijfstypen voor de akkerbouw. In de opdracht lag de nadruk op de melkveehouderij. Voor de akkerbouw is een eerste uitwerking van de meerkosten afgesproken.

5. In dit onderzoek is per bedrijfstype een maatregelenpakket samengesteld om van niveau $A$ (uitgangssituatie) naar niveau B (na te streven hoger niveau) te gaan. De algemene beschrijving van de bedrijfstypen is als vertrekpunt gebruikt om een selectie te maken uit het Bedrijveninformatienet van Wageningen Economic Research. Niveau A en B worden gekwantificeerd met behulp van praktijkgegevens die zijn vastgelegd in het Informatienet van Wageningen Economic Research (zie figuur 2.1 voor melkvee en figuur 2.2 voor akkerbouw). Het Bedrijveninformatienet is een gestratificeerde representatieve steekproef van zo'n 1.500 land- en tuinbouwbedrijven, waarvan ongeveer 330 melkveebedrijven en ongeveer 210 akkerbouwbedrijven. Elk bedrijf in de steekproef heeft een zogenaamde wegingsfactor die aangeeft voor welk aantal bedrijven uit de gehele populatie zo'n bedrijf representatief is. Het Bedrijveninformatienet bevat van elk bedrijf informatie over bedrijfsopzet en bedrijfsvoering, technische en bedrijfseconomische (profit) resultaten, resultaten op diverse duurzaamheidsthema's zoals fosfaat- en stikstofbodemoverschot, en gebruik van gewasbeschermingsmiddelen (Ge, 2018). Niet alle bedrijven worden in de analyse meegenomen omdat bedrijven met meer dan 50\% lössgrond niet zijn opgenomen. Daarnaast waren de KPIs niet voor alle bedrijven beschikbaar en konden die bedrijven niet worden meegenomen.

1 http://biodiversiteitsmonitormelkveehouderij.nl/docs/Biodiversiteitsmonitor_nederlands.pdf 


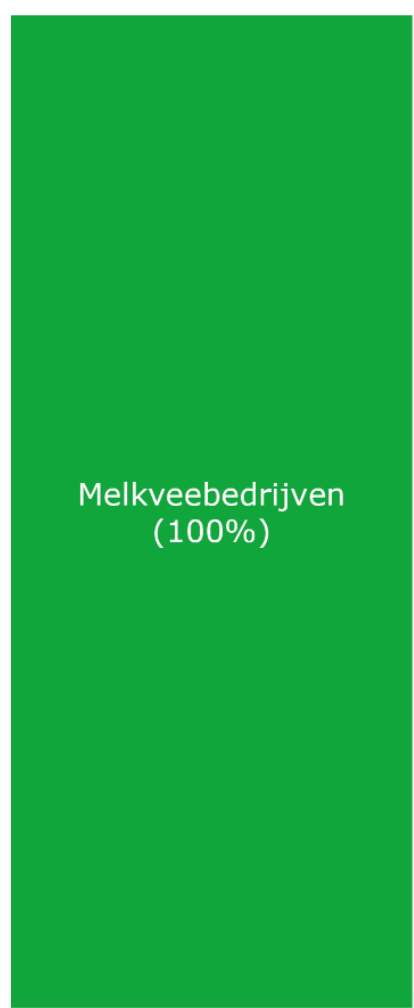

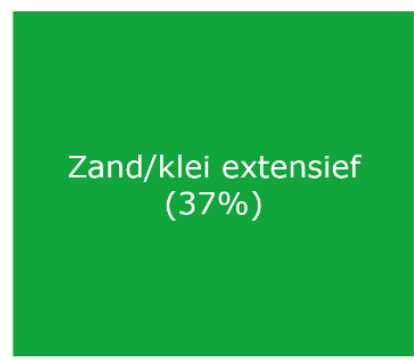

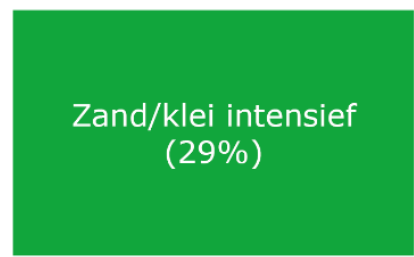

Veen

$(11 \%)$
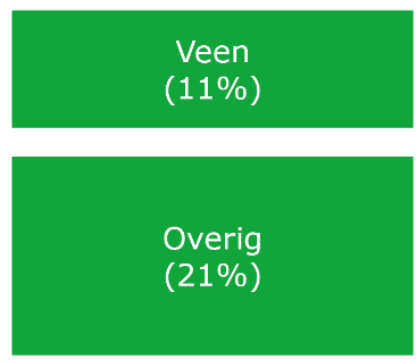

\section{B (30\%)}

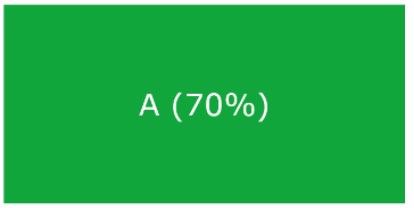

B $(30 \%)$

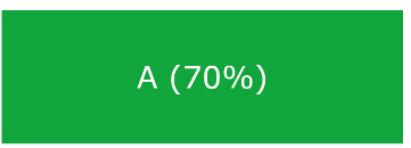

B $(30 \%)$

A $(70 \%)$

Figuur 2.1 Indeling bedrijfstypen. Links staat de totale populatie melkveebedrijven (100\%). Deze is opgedeeld in drie bedrijfstypen: zand/klei extensief, zand/klei intensief en veen. Vervolgens is per bedrijfstype een groep $A$ en een beter scorende groep $B$ onderscheiden.

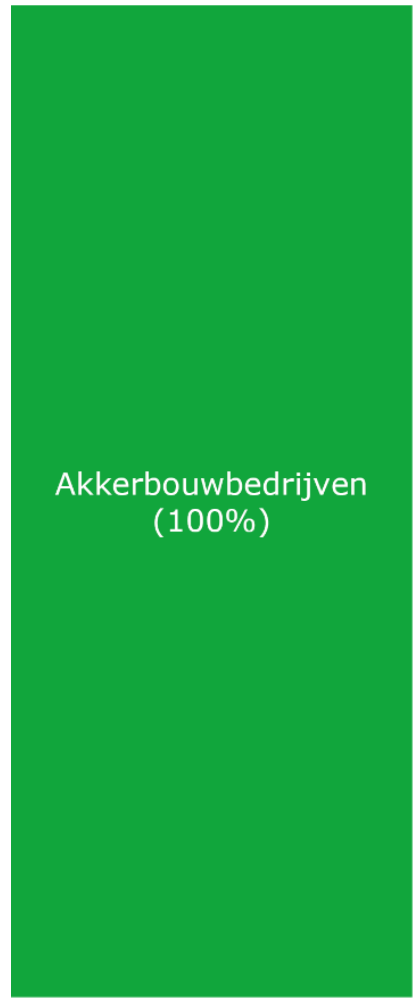

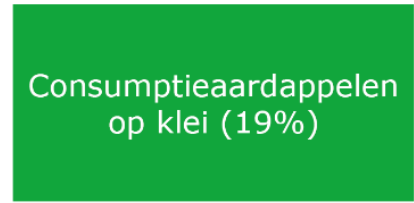

Zetmeelaardappelen op zand $(9 \%)$

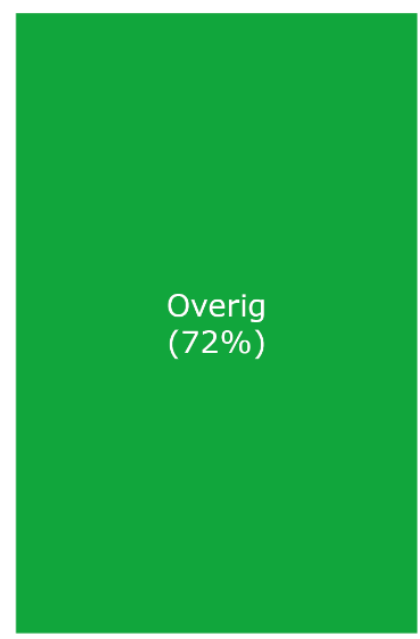

\section{B $(30 \%)$}

\section{A $(70 \%)$}

B $(30 \%)$

A $(70 \%)$

Figuur 2.2 Indeling bedrijfstypen. Links staat de totale populatie akkerbouwbedrijven (100\%). Deze is opgedeeld in twee bedrijfstypen: consumptieaardappelbedrijven op klei en zetmeelaardappelbedrijven op zand. Vervolgens is per bedrijfstype een groep $A$ en een beter scorende groep $B$ onderscheiden. 
Niveau $B$ is het niveau dat momenteel gemiddeld wordt gehaald door $30 \%$ van de bedrijven. Deze bedrijven scoren integraal het beste op de KPI's. Niveau A is het gemiddelde van de overige $70 \%$ van de bedrijven. In het onderzoek zijn uitsluitend gangbare bedrijven meegenomen en er is uitgegaan van gemiddelde productieomstandigheden. Niveau B is geen einddoel of normniveau voor biodiversiteit en ook niet het droombeeld voor het Deltaplan. Dit beeld is in dit onderzoek niet ingevuld en doorgerekend. Dit maakte ook geen deel uit van de onderzoeksopdracht. De begeleidingsgroep heeft aangegeven het wel belangrijk te vinden dat ook de meerkosten van het droombeeld worden bepaald. Op dit moment is dat nog niet mogelijk, omdat dit droombeeld onvoldoende is geconcretiseerd. Het Deltaplan heeft in 2019 een droombeeld geschetst dat begint met:

'In 2030 herbergt de groene ruimte van Nederland een rijke biodiversiteit aan onder andere bodemleven, planten, insecten en boerenlandvogels. Het landschap sprankelt van de diversiteit en mensen leven, werken en recreëren er graag. Landschappen zijn herkenbaar aan hun inrichting en begroeiing, mensen identificeren zich hiermee en zijn er trots op.'

Dit droombeeld is nog niet vertaald naar een concrete invulling van biodiversiteitsdoelen en maatregelen voor diverse bedrijfstypen voor melkvee en akkerbouw. Onder andere in de workshop kwamen wel bouwstenen langs voor dit niveau. Voor melkvee ging het hier bijvoorbeeld om een groter aandeel kruidenrijk grasland, het achterwege laten van kunstmest, werken met gescheiden mest of vaste mest en het voldoen aan de drempelwaarden uit de biodiversiteitsmonitor. Voor akkerbouw werd bijvoorbeeld strokenteelt genoemd als een mogelijk belangrijke bouwsteen.

6. Het onderzoek richt zich op maatregelen voor de brede groep van praktijkbedrijven die op relatief korte termijn (de komende vijf jaar) genomen kunnen worden. Maatregelen waarbij de bedrijfsstructuur verandert en maatregelen waarvoor meer dan vijf jaar nodig zijn om ze te kunnen implementeren, zijn niet meegenomen. Ook meer experimentele maatregelen zijn niet meegenomen gegeven de onzekerheid rond deze maatregelen.

7. Vertrekpunt is bestaande wet- en regelgeving en de huidige marktsituatie voor inputs en outputs in de landbouw. Dat wil zeggen dat er geen rekening wordt gehouden met mogelijke prijsveranderingen en/of wijzigingen in wet- en regelgeving en eventuele subsidies.

\subsection{Aanpak vaststellen van bedrijfstypen en huidige niveau bedrijfsvoering}

De drie bedrijfstypen voor melkveehouderij en de twee bedrijfstypen voor akkerbouw zijn vastgesteld in overleg met de begeleidingsgroep.

Voor de melkveehouderij is gekozen voor de volgende bedrijfstypen:

- extensief bedrijf op zand/klei

- intensief bedrijf op zand/klei

- bedrijf op veen

De belangrijkste gedachte achter het afzonderlijk opnemen van een bedrijfstype op veen is dat op veengrond de bedrijfsvoering duidelijk anders is en er ook andere maatregelen mogelijk of nodig zijn dan op andere grondsoorten. Veenbedrijven zijn over het algemeen voornamelijk gebaseerd op gras. Snijmais of andere akkerbouwmatige teelten passen niet goed op veengrond. Het onderscheid tussen intensief en extensief is vooral ingegeven door het feit dat de bedrijfsvoering op intensieve bedrijven anders is dan op extensieve bedrijven, wat bijvoorbeeld resulteert in een gemiddeld hogere melkproductie per koe, en dat de opbouw van de kostprijs anders is door bijvoorbeeld de hogere voeraankopen. Voor extensieve bedrijven is er meestal (ruim) voldoende ruwvoer.

Het onderscheid in grondsoort is gebaseerd op de meest voorkomende grondsoort van het bedrijf. Bedrijven met meer dan $50 \%$ veen zijn als veenbedrijf aangemerkt. De resterende bedrijven zijn in de groep zand/klei-bedrijven ingedeeld. Enige uitzondering hierop vormt een beperkt aantal bedrijven met meer dan 50\% löss. Deze bedrijven zijn niet in het onderzoek meegenomen. De groep bedrijven 
op zand/klei is vervolgens onderverdeeld in twee qua omvang vrijwel gelijke groepen op basis van de mediaan voor gve per ha. Bedrijven met minder dan 2,45 gve per ha zijn ingedeeld in de groep extensief, bedrijven met 2,45 gve per ha of meer in de groep intensief. Deze bedrijfstypen representeren gezamenlijk een groot deel van de Nederlandse melkveebedrijven (zie ook paragraaf 3.2.1).

\section{Bedrijfstypen akkerbouw}

Voor de akkerbouw is gekozen voor een onderscheid naar zand en klei. Ongeveer de helft van het akkerbouwareaal ligt op klei- en zavelgrond, de andere helft op zand- en dalgrond en op löss (Smit en Jager, 2018). Dit verschil in grondsoort bepaalt een deel van de verschillen in bouwplan en bedrijfsvoering in de akkerbouwgebieden, en daarmee van het landschap in de gebieden en het karakter van dat landschap. Zand en klei verschillen in luchtgehalte, vochtvasthoudend vermogen en structuur, en daardoor in bewerkbaarheid van de grond (zie ook Smit en Jager, 2018). Zware kleigrond blijft in het voorjaar lang nat en koud en kan daardoor later bewerkt worden dan bijvoorbeeld zand- of dalgrond. Ook kost de bewerking van deze grondsoort (zoals ploegen) meer energie. Daar staat tegenover dat zwaardere gronden meestal vruchtbaarder zijn dan de lichtere gronden en bij droogte langer water aan het gewas af kunnen geven.

Binnen beide grondsoorten zijn de bouwplannen niet voor elk bedrijf hetzelfde. In de veenkoloniën ligt bijvoorbeeld de nadruk sterk op zetmeelaardappelen, terwijl in andere regio's de nadruk meer op consumptie- en pootaardappelen ligt. Voor kleigrond geldt een vergelijkbare situatie met bijvoorbeeld bedrijven met een relatief groot aandeel graan in het Oldambt ten opzichte van bedrijven met een groter aandeel suikerbieten en consumptie- of pootaardappelen in andere regio's. Een gemiddeld bouwplan voor zand of klei zegt daardoor eigenlijk niet veel en is in ieder geval niet herkenbaar voor de praktijk. Daarom is besloten om voor specifieke groepen te kiezen die herkenbaar zijn, namelijk akkerbouwbedrijven met een veenkoloniaal bouwplan (20-60\% zetmeelaardappelen in het bouwplan) en consumptieaardappeltelende bedrijven op kleigrond (10-35\% in het bouwplan). Een nadeel is dat deze twee bedrijfstypen een beperkt deel van de akkerbouwsector vertegenwoordigen (zie paragraaf 3.2.2).

\section{Gebruikte KPI's melkvee}

De KPI's uit de biodiversiteitsmonitor waren niet allemaal beschikbaar binnen het Informatienet. Het aandeel kruidenrijk grasland en het percentage beheerd grasland worden niet in het Informatienet vastgelegd. Omdat juist de combinatie van indicatoren belangrijk is binnen de biodiversiteitsmonitor, is met proxy's gewerkt voor deze twee indicatoren. De gebruikte proxy's zijn: de ontvangen beheervergoeding per hectare cultuurgrond (in euro) en het aantal vormen van natuurbeheer dat een melkveehouder toepast. De laatste indicator is gebaseerd op een vraag die jaarlijks aan de Informatienet-deelnemers met een melkveebedrijf wordt gesteld ten behoeve van de jaarlijkse sectorrapportage van de Duurzame Zuivelketen. De vraag is of de melkveehouder de volgende vier vormen van natuurbeheer al dan niet toepast: 1) soortenbeheer, 2) botanisch beheer randen, 3) botanisch beheer percelen en 4) onderhoud landschapselementen. Voor elke vorm kan dus ja of nee worden opgegeven. In deze analyse is dit vertaald naar één kengetal, namelijk 'aantal toegepaste vormen van natuurbeheer'. De score kan hierbij variëren van 0 (geen natuurbeheer) tot 4 (alle vier de vormen van natuurbeheer). In tabel 2.1 zijn de indicatoren uit de biodiversiteitsmonitor en de gebruikte beschikbare indicatoren uit het Bedrijveninformatienet naast elkaar gezet. 
Tabel 2.1 Indicatoren uit de Biodiversiteitsmonitor Melkveehouderij en de in dit onderzoek gebruikte indicatoren uit het Bedrijveninformatienet.

\begin{tabular}{|c|c|c|}
\hline KPI uit biodiversiteitsmonitor & KPI Bedrijveninformatienet & Toelichting \\
\hline Percentage blijvend grasland & Percentage blijvend grasland & \\
\hline $\begin{array}{l}\text { Percentage eiwit van eigen bedrijf/uit } \\
\text { eigen regio }(<20 \mathrm{~km})\end{array}$ & Percentage eiwit van eigen bedrijf & $\begin{array}{l}\text { In het Informatienet is geen informatie } \\
\text { beschikbaar over eiwit dat uit de regio } \\
\text { binnen een afstand van } 20 \mathrm{~km} \text { wordt } \\
\text { aangevoerd. }\end{array}$ \\
\hline Ammoniakemissie (kg/ha) & Ammoniakemissie (kg/ha) & \\
\hline $\begin{array}{l}\text { Uitstoot van broeikasgassen ( } \mathrm{kg} \mathrm{CO} \text {-eq } \\
\text { per } \mathrm{kg} \text { melk en } \mathrm{kg} \mathrm{CO} \text {-eq per ha) }\end{array}$ & 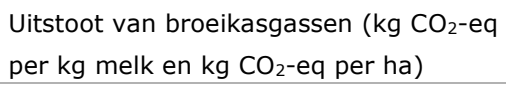 & \\
\hline Percentage kruidenrijk grasland & Aantal vormen van natuurbeheer ${ }^{2}$ & $\begin{array}{l}\text { Er is gebruikgemaakt van deze } \\
\text { proxyvariabele voor het percentage } \\
\text { kruidenrijk grasland omdat deze } \\
\text { variabele op dit moment niet } \\
\text { beschikbaar is in het Informatienet. }\end{array}$ \\
\hline $\begin{array}{l}\text { Percentage beheerd land met } \\
\text { beheercontract }\end{array}$ & Beheersvergoeding per ha & $\begin{array}{l}\text { Er is gebruikgemaakt van deze proxy } \\
\text { voor het percentage beheerd land met } \\
\text { beheerscontract omdat deze variabele } \\
\text { op dit moment niet beschikbaar is in } \\
\text { het Informatienet. }\end{array}$ \\
\hline
\end{tabular}

Een nadere toelichting voor een aantal KPI's:

- Percentage blijvend grasland: afgeleid uit landbouwtellingsgegevens. Het gaat om grasland dat minimaal vijf jaar grasland is op de peildatum.

- Percentage eiwit van eigen bedrijf/uit eigen regio: binnen het Bedrijveninformatienet is alleen bekend welk percentage van het benodigde eiwit op het eigen bedrijf wordt geteeld en niet welk deel van het eiwit afkomstig is uit een straal van $20 \mathrm{~km}$ rond het bedrijf. Het absolute niveau van de indicator zoals die in het Informatienet beschikbaar is, komt dus niet overeen met de definitie uit de biodiversiteitsmonitor. Dit geldt echter voor alle bedrijven. We gaan ervan uit dat dit niet van invloed is op het verschil tussen niveau A en B. De berekening van het kengetal is uitgevoerd met de Kringloopwijzer (Schröder et al., 2019).

- De berekeningen van het $\mathrm{N}$-bodemoverschot per hectare en de ammoniakemissie per hectare zijn gebaseerd op de Kringloopwijzer.

- Voor de uitstoot van broeikasgassen noemt de biodiversiteitsmonitor twee indicatoren, namelijk de emissie van $\mathrm{CO}_{2}$-equivalenten per $\mathrm{kg}$ melk en de emissie van $\mathrm{CO}_{2}$-equivalenten per ha. Beide indicatoren zijn in overleg met de begeleidingsgroep meegenomen. Om ervoor te zorgen dat de uitstoot van broeikasgassen niet zwaarder weegt dan de andere afzonderlijke indicatoren, is ervoor gekozen om beide indicatoren een weging van 0,5 te geven. De broeikasgasemissies zijn berekend met behulp van de Kringloopwijzer. Er is geen allocatie (naar melk en vlees) toegepast. Dit is een reden dat de getallen in deze rapportage hoger zijn dan bijvoorbeeld in de sectorrapportage zoals die voor Duurzame Zuivelketen wordt gemaakt (Doornewaard et al, 2018).

\section{KPI's akkerbouw}

De KPI's die voor de akkerbouw zijn gebruikt, zijn met name gebaseerd op input uit de expertworkshop (tabel 2.2). Daarnaast was de beschikbaarheid van de indicatoren in het Informatienet ook een bepalende factor.

\footnotetext{
2 Soortenbeheer, botanisch beheer randen, botanisch beheer percelen, onderhoud landschapselementen. De score kan dus variëren van 0 tot 4 .
} 
Tabel 2.2 KPI's gebruikt als biodiversiteitsindicator voor akkerbouw.

\begin{tabular}{|c|c|}
\hline Indicator & Toelichting \\
\hline Percentage rustgewassen & $\begin{array}{l}\text { Rustgewassen zijn gewassen als granen, graszaad, koolzaad, luzerne en mais. } \\
\text { Rustgewassen worden op akkerbouwbedrijven in het bouwplan opgenomen in rotatie } \\
\text { met rooigewassen. Rustgewassen dragen bij aan de organischestofbalans, } \\
\text { verbeteren de bodemstructuur en verminderen bodemgebonden ziekten en plagen. } \\
\text { De biodiversiteit is gebaat bij deze rustgewassen: insecten, bodemorganismen, } \\
\text { vogels en kleine zoogdieren komen hierin meer voor dan in rooigewassen. }\end{array}$ \\
\hline Percentage groenbemester & $\begin{array}{l}\text { De teelt van groenbemesters zorgt onder meer voor een gezonde bodem, } \\
\text { bodembedekking, organische stof, behoud van stikstof en kali in de bodem } \\
\text { (reduceren uitspoeling) en verbetering van de bodemstructuur. }\end{array}$ \\
\hline Organischestofbalans & $\begin{array}{l}\text { Organische stof in de bodem is essentieel voor een optimale teelt van gewassen. } \\
\text { Organische stof verhoogt het waterbergend vermogen, de bewortelbaarheid en de } \\
\text { structuur van de bodem. Met name het bodemleven profiteert hiervan. Voor vogels } \\
\text { en kleine zoogdieren levert organische stof voedsel. In deze studie is alleen de } \\
\text { aanvoer van effectieve organische stof gekwantificeerd met behulp van normgetallen } \\
\text { per activiteit. De afbraak hangt af van het percentage organische stof in de } \\
\text { bouwvoor en de afbraaksnelheid. Voor deze beide variabelen zijn geen } \\
\text { bedrijfsgegevens voorhanden. Globaal ligt dit tussen de } 1500 \text { en } 2500 \mathrm{~kg} \text { per ha. }\end{array}$ \\
\hline $\mathrm{N}$-overschot $(\mathrm{kg} / \mathrm{ha})$ & $\begin{array}{l}\text { Een hoog stikstofbodemoverschot kan leiden tot uitspoeling van nitraat en } \\
\text { eutrofiëring van het oppervlaktewater. }\end{array}$ \\
\hline Agrarisch natuurbeheer ( $€ /$ ha) & $\begin{array}{l}\text { Agrarisch natuurbeheer is bij uitstek bedoeld om de biodiversiteit te bevorderen. In } \\
\text { deze studie is het bedrag aan ontvangen vergoedingen een proxyvariabele, die } \\
\text { vertaald is naar de oppervlakte bloeiende akkerranden. Positieve punten zijn de } \\
\text { toename van de gewasdiversiteit, het aantal insecten, de nestgelegenheid voor } \\
\text { broedvogels, de foerageerplaatsen en de schuilgelegenheid voor zoogdieren. }\end{array}$ \\
\hline
\end{tabular}

Binnen elk bedrijfstype is gekeken naar de gemiddelde score op de individuele KPI's van de $30 \%$ best scorende bedrijven en het niveau van de overige $70 \%$ van de bedrijven. Het niveau van de overige $70 \%$ wordt in dit rapport verder aangeduid als niveau A (uitgangsniveau), het niveau van de $30 \%$ best presterende bedrijven als niveau $B$.

Niveau A en B zijn vastgesteld op basis van een rangordesystematiek (gebaseerd op Daatselaar et al., 2018).

Dit gebeurt in de volgende stappen:

1. Voor elk bedrijfstype zijn de bedrijven per biodiversiteits-KPI op volgorde gezet van laag naar hoog.

2. Hoog is soms gunstig (bijv. eiwit van eigen land), soms ongunstig (bijv. N-bodemoverschot);

3. Per KPI krijgen bedrijven met de gunstigste ranking een 1 , bedrijven met de ongunstigste ranking een 0 en de rest zit ertussenin;

4. Per bedrijf worden de scores per KPI (zeven stuks voor melkvee, acht stuks voor akkerbouw) opgeteld. Dit betekent dat feitelijk een totaalscore over alle KPI's wordt berekend;

5. De $30 \%$ bedrijven binnen een bedrijfstypegroep met de hoogste totaalscore vormt samen de groep die resulteert in niveau $B$;

6. De $70 \%$ bedrijven binnen een bedrijfstypegroep met de laagste totaalscore vormt samen de groep die resulteert in niveau $\mathrm{A}$. 


\subsection{Aanpak definiëren van maatregelenpakketten}

De maatregelenpakketten voor de verschillende bedrijfstypen zijn in een aantal stappen vastgesteld:

1. Opstellen van een longlist van maatregelen op basis van bestaande literatuur en andere bronnen, die vervolgens is ingedikt om tot een te hanteren lijst van maatregelen te komen voor de workshop. De lijst is ingedeeld in verschillende categorieën. De gebruikte literatuur is opgenomen in bijlage 2;

2. Workshop met experts die op basis van de ingedikte lijst maatregelen zijn gekomen tot prioritering en concretisering per bedrijfstype en maatregeltype. Als check van stap 1 is gekeken of er maatregelen of categorieën gemist werden in de ingedikte lijst;

3. Nadere concretisering en kwantitatieve invulling van maatregelenpakketten per bedrijfstype op basis van:

a. het resultaat van de expertworkshop (prioritering en discussie);

b. de verschillen in kenmerken van de gemiddelde Informatienetbedrijven achter niveau $A$ en niveau $B$;

4. Review van de maatregelenpakketten door experts.

Het doel van de workshops was om met behulp van de input van experts tot een prioritering en concretisering van maatregelen te komen voor de verschillende bedrijfstypen. De workshop startte met een algemene toelichting op de aanpak van het onderzoek. Dit leverde goede input en reflectie op van de experts, die is meegenomen in de samenstelling van de pakketten en in de discussie van dit rapport (bijlage 3: lijst met deelnemers). Vervolgens werd in deelsessies (melkvee en akkerbouw) specifiek ingegaan op de te nemen maatregelen. Dit gebeurde met hulp van de Mentimeter-tool. Met de Mentimeter-tool kon elke expert individueel antwoorden geven op centraal gestelde vragen, waarna het resultaat van de groep centraal kon worden gedeeld. De Mentimeter-tool is gebruikt om de discussie te structureren en om mogelijke maatregelen te delen met de experts. Er was in de workshop ruimte voor experts om maatregelen toe te voegen als check op de samengestelde lijst.

Als eerste stap werd gevraagd om het belang van de verschillende categorieën aan te geven. Daarbij is steeds aangegeven dat het doel is om tot een integrale verbetering op alle KPI's te komen. Via de Mentimeter-tool kon elke deelnemer zelf een score aangeven. Deze scores werden door de tool gemiddeld en als resultaat op het scherm getoond (figuur 2.3). Vervolgens werd elke categorie afzonderlijk bekeken. Per categorie kwam een aantal concrete maatregelen in beeld, en de deelnemende experts werd gevraagd om de drie belangrijkste maatregelen te prioriteren. Concreet werd gevraagd om de belangrijkste, de een-na-belangrijkste en de twee-na-belangrijkste maatregel aan te geven. De overkoepelende vraag was steeds welke maatregelen het meest bijdroegen aan de KPI's. De score van de groep kwam in beeld en deze score werd vervolgens in de groep besproken. In de discussie kwamen door uitwisseling van argumenten soms nieuwe inzichten naar voren, en soms werden maatregelen geconcretiseerd of gekwantificeerd.

\section{Welke 3 maatregelen graslandbeheer dragen het meeste bij aan de KPIs?}

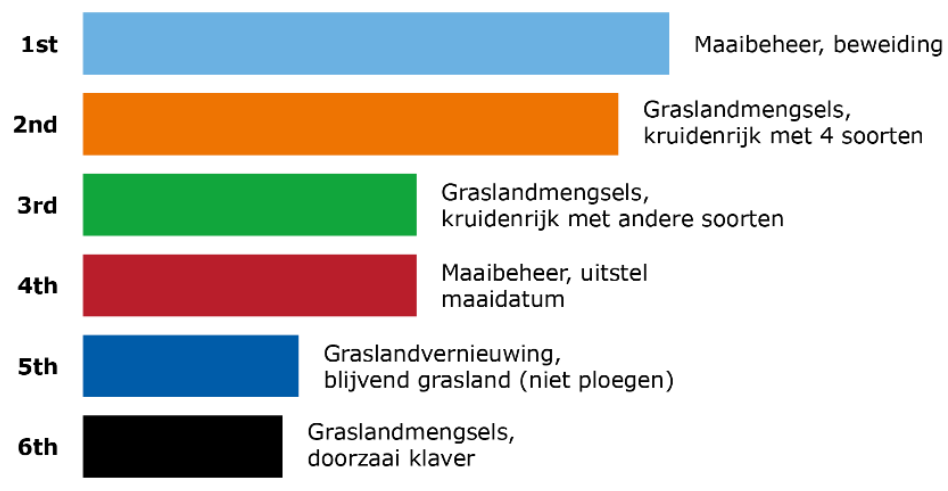

Figuur 2.3 Voorbeeld van een resultaat van de Mentimeter-tool. 
De aanpak werd per bedrijfstype gevolgd. De kengetallen voor de KPI's van de biodiversiteitsmonitor van niveau A en B waren voor alle deelnemers van de workshop melkveehouderij beschikbaar op papier. De biodiversiteitsmonitor-KPI's waren aangevuld met structuur- en bedrijfsvoeringskenmerken om een idee te krijgen van het gemiddelde beeld van de bedrijven die niveau A respectievelijk B vormen. Voor akkerbouw begon de workshop met het een discussie over de KPI's. Hier waren daarom geen praktijkgegevens beschikbaar voor de deelnemers.

\section{Nadere kwantitatieve invulling van maatregelen}

Op basis van de resultaten van de workshop is het projectteam aan de slag gegaan om tot concrete maatregelenpakketten per bedrijfstype te komen. Dit is gebeurd op basis van de volgende uitgangspunten:

- Het gemiddelde bedrijf van niveau A moet in de nieuwe situatie de score van niveau B halen voor de KPI's van de biodiversiteitsmonitor. Het bedrijf is na het nemen van de maatregelen geen volledige kopie qua bedrijfsstructuur en bedrijfsvoering van een bedrijf dat hoort bij niveau $\mathrm{B}$;

- Het onderzoek richt zich op maatregelen die de komende vijf jaar uitgevoerd kunnen worden. Dit betekent dat er ook is gekeken naar de termijn waarop de maatregel kan worden genomen. Maatregelen die bijvoorbeeld grote aanpassingen in stalsystemen vragen, zijn niet meegenomen in de berekeningen. Grote stalaanpassingen zullen met name worden doorgevoerd als stallen zijn afgeschreven en/of aan vervanging toe zijn. Hierbij gaat het om termijnen van minimaal twintig jaar. Dit type maatregelen past wel bij het lange termijn droombeeld van het Deltaplan;

- In de nieuwe situatie wordt hetzelfde melkvolume geproduceerd. Dit betekent dat als er bijvoorbeeld een maatregel wordt genomen die leidt tot een lagere voerproductie, dit wordt gecompenseerd door voeraankoop. Het streven is ook om de productie binnen de bestaande bedrijfsstructuur in te vullen, dat wil zeggen in bestaande stallen en op de bedrijfsoppervlakte in de uitgangssituatie;

- De keuze en concrete invulling van de maatregelen gebeurt op basis van:

- de aangegeven prioritering van de maatregelen in de expertworkshop;

- de concretisering en/of nuancering van de maatregelen uit discussie in de expertworkshop;

- de termijn van invoering van de maatregelen.

De mate waarin een maatregel wordt doorgevoerd (dus bijvoorbeeld hoeveel maisland wordt vervangen door grasland) is mede gebaseerd op verschillen in bedrijfsvoering tussen gemiddelden achter niveau $A$ en niveau $B$.

De samengestelde maatregelenpakketten zijn gereviewd door experts. Voor de melkveebedrijven is de review uitgevoerd door Frits van der Schans (CLM) en Nick van Eekeren (Louis Bolk Instituut). Voor de akkerbouwbedrijven is de review uitgevoerd door Jaap van Wenum (LTO). De review voor de akkerbouwbedrijven had met name betrekking op de type maatregelen, de kwantitatieve invulling is bepaald door het te bereiken niveau. De input van de reviewers heeft met name voor de melkveebedrijven geleid tot aanpassingen in de pakketten.

\subsection{Aanpak berekening meerkosten}

De meerkosten zijn per maatregel per bedrijfstype berekend op basis van de gemiddelde situatie (gebaseerd op het Bedrijveninformatienet) van de betreffende groep. Het Informatienetgemiddelde van de $70 \%$ minder goed presterende bedrijven (niveau A) vormt als het ware het prototype van het bedrijf waarvoor de meerkosten zijn uitgerekend.

Per bedrijfstype zijn vervolgens per maatregelen de meerkosten berekend. Dit is gedaan door te kijken of er voor een maatregel extra operationele kosten of investeringen nodig zijn. Eventueel benodigde investeringen zijn op basis van afschrijving en rente teruggerekend naar jaarkosten. Als bijvoorbeeld extra loonwerk nodig is, dan worden hiervan ook de kosten berekend. Extra arbeid van de ondernemer is gewaardeerd op $€ 35$ per uur (Polman et al., 2015). Eventuele lagere voeropbrengsten door een maatregel, bijvoorbeeld het omzetten van gras in mais, worden gecompenseerd door extra voeraankopen. Effecten van dit soort maatregelen zijn waar mogelijk afgeleid van gegevens uit het Bedrijveninformatienet. In het voorbeeld van de omzetting van mais naar gras geldt dus dat de kosten die gemaakt moeten worden voor extra voeraankopen zijn gebaseerd op het verschil in KvEM-opbrengst van de Informatienetbedrijven. Als de effecten niet uit 
het Informatienet zijn af te leiden dan is gebruikgemaakt van eerder uitgevoerd onderzoek of zijn experts geraadpleegd. Prijsniveaus zijn afgeleid van KWIN veehouderij en KWIN AGV.

Sommige maatregelen leveren ook besparingen op. Minder gebruik van kunstmest leidt uiteraard tot lagere kosten voor kunstmest. Dit is ook meegenomen in de totale berekening van de meerkosten. Voor melkvee zijn de kosten toegerekend aan de productie van melk, voor akkerbouw zijn de meerkosten per hectare berekend.

De kosten voor de natuurbeheermaatregelen zijn op een andere manier benaderd. De beheervergoeding (website bij12.nl) vormt de basis voor de meerkosten in dit onderzoek. Er is geen rekening gehouden met een eventueel te ontvangen beheervergoeding omdat de vergoeding niet voor heel Nederland geldt, maar alleen voor specifieke gebieden. Het aantal mogelijke beheerpakketten is in de praktijk erg groot. De gekozen pakketten in dit onderzoek moeten daarom als voorbeelden worden beschouwd. Op specifieke locaties zullen andere pakketten mogelijk beter passen.

Voor vrijwel elke afzonderlijke maatregel zou een afzonderlijk (langjarig) onderzoeksproject kunnen worden uitgevoerd alleen al om bijvoorbeeld de technische effecten op gewasopbrengsten en melkproductie per koe te bepalen en om daar vervolgens weer de economische effecten van te bepalen. Dit valt echter buiten de context van de onderzoeksvraag en de beschikbare (doorloop)tijd. Effecten van diverse afzonderlijke maatregelen zijn naast de review ook besproken met/getoetst bij experts binnen en buiten Wageningen University \& Research. 


\section{Resultaten}

\subsection{Bedrijfstypen en niveau A en B}

\subsubsection{Bedrijfstypen en indicatoren melkvee}

De analyse is gebaseerd op gegevens uit 2017. Dit was landelijk een relatief normaal jaar qua weersomstandigheden. In dit onderzoek is vooral gekeken naar verschillen in de score op KPI's tussen groepen binnen een specifiek bedrijfstype. Er is niet gekeken hoe de verschillen over de jaren variëren. In de toekomst kunnen meerdere jaren worden meegenomen.

In tabel 3.1 zijn per bedrijfstype voor niveau A en B de gemiddelden voor bedrijfskenmerken en de score op de KPI's voor biodiversiteit weergegeven. De in het onderzoek gebruikte melkveebedrijven uit het Bedrijveninformatienet representeren 12.866 melkveebedrijven. In 2017 waren er in totaal 16.330 melkveebedrijven in Nederland (CBS, 2019). De in het onderzoek betrokken Informatienetbedrijven representeren daarmee $79 \%$ van het totaalaantal bedrijven.

Tabel 3.1 Bedrijfskenmerken en score op biodiversiteits-KPI's voor verschillende bedrijfstypen melkvee en niveau $A$ en $B$ (2017).

\begin{tabular}{|c|c|c|c|c|c|c|}
\hline & \multicolumn{6}{|c|}{ Bedrijfstype } \\
\hline & \multicolumn{2}{|c|}{ Extensief klei/zand } & \multicolumn{2}{|c|}{ Intensief klei/zand } & \multicolumn{2}{|c|}{ Veen } \\
\hline & A & B & A & B & A & B \\
\hline Aantal Informatienetbedrijven per categorie & 66 & 28 & 63 & 27 & 23 & 10 \\
\hline \multicolumn{7}{|l|}{ Informatienetbedrijven vertegenwoordigt } \\
\hline \multicolumn{7}{|l|}{$\begin{array}{l}\text { Informatienetbedrijven vertegenwoordigt } \\
(\%)\end{array}$} \\
\hline \multicolumn{7}{|l|}{ Bedrijfskenmerken } \\
\hline Koeien (aantal) & 115 & 100 & 158 & 158 & 128 & 92 \\
\hline Cultuurgrond (ha) & 67,4 & 63,2 & 60,7 & 71,8 & 68,6 & 50,8 \\
\hline Gras (ha) & 55,4 & 52,6 & 46,9 & 61,9 & 62,1 & 48,7 \\
\hline Mais (ha) & 9,9 & 9,4 & 12,0 & 9,9 & 6,5 & 2,0 \\
\hline Veebezetting (gve/ha) & 2,2 & 2,0 & 3,3 & 2,7 & 2,5 & 2,2 \\
\hline Melkproductie bedrijf $(\mathrm{kg})$ & 1.043 .225 & 844.733 & 1.472 .234 & 1.392 .637 & 1.134 .649 & 769.290 \\
\hline Intensiteit (kg melk/ha) & 15.286 & 13.277 & 24.266 & 18.503 & 16.415 & 13.854 \\
\hline \multicolumn{7}{|l|}{ Score op KPI's biodiversiteit ${ }^{*}$} \\
\hline Ranking & 2,8 & 3,9 & 2,8 & 4,1 & 3,2 & 4,6 \\
\hline $\begin{array}{l}\text { Aandeel blijvend grasland (\% van totaal } \\
\text { grasland) }\end{array}$ & 66 & 89 & 48 & 86 & 86 & 100 \\
\hline Aandeel eiwit eigen land (\%) & 64 & 74 & 50 & 71 & 67 & 74 \\
\hline $\mathrm{N}$-bodemoverschot $(\mathrm{kg} / \mathrm{ha})$ & 163 & 127 & 134 & 89 & 301 & 296 \\
\hline $\mathrm{NH}_{3}$-emissie $(\mathrm{kg} / \mathrm{ha})$ & 61 & 56 & 77 & 71 & 73 & 74 \\
\hline $\mathrm{CO}_{2}$-emissie totaal $(\mathrm{kg} \mathrm{eq} / 1.000 \mathrm{~kg}$ melk) & 1.602 & 1.612 & 1.580 & 1.598 & 1.905 & 1.983 \\
\hline $\mathrm{CO}_{2}$-emissie totaal (kg eq/ha) & 24.221 & 21.113 & 38.057 & 29.063 & 30.794 & 26.650 \\
\hline Vormen natuurbeheer (aantal, max. is 4$)^{* *}$ & 0,9 & 1,9 & 0,3 & 1,2 & 0,9 & 3,0 \\
\hline $\begin{array}{l}\text { Subsidie uit agrarisch natuurbeheer } \\
\text { (euro/ha) }{ }^{* * *}\end{array}$ & 9 & 71 & 0 & 41 & 13 & 140 \\
\hline
\end{tabular}


De bedrijven in groep B scoren tussen de 1,1 en 1,4 hoger dan groep A. Daarbij moet opgemerkt worden dat de scores gegeven de methodiek die in dit onderzoek is gehanteerd niet vergelijkbaar zijn over de bedrijfstypen heen. De score is namelijk relatief ten opzichte van andere bedrijven binnen het bedrijfstype en niet relatief ten opzichte van de hele populatie.

In tabel 3.1 is zichtbaar dat de bedrijven in groep B voor alle bedrijfstypen op vrijwel alle afzonderlijke KPI's beter scoren dan de bedrijven in groep A. Dit is niet vanzelfsprekend: de selectie is gebaseerd op een totaalscore op de KPI's, maar er zijn geen ondergrenzen op individuele KPI's gehanteerd.

Uitzonderingen hierop zijn de ammoniakemissie per ha bij het bedrijfstype veen en de $\mathrm{CO}_{2}$-emissie per $\mathrm{kg}$ melk voor alle bedrijfstypen. Intensiteit (melk per ha) heeft een vrij directe relatie met $\mathrm{CO}_{2}$-emissie per ha. Hoe extensiever het bedrijf, hoe lager de emissie per ha. Voor de $\mathrm{CO}_{2}$-emissie per $\mathrm{kg}$ melk is de relatie omgekeerd: intensieve bedrijven hebben gemiddeld een wat lagere emissie per kg melk. Omdat ook andere indicatoren min of meer aan intensiteit gekoppeld zijn $\left(\mathrm{NH}_{3}\right.$-emissie per ha, aandeel eiwit van eigen land), is groep B gemiddeld wat extensiever.

Het is belangrijk om te benadrukken dat beide niveaus afgeleid zijn van de huidige praktijkgegevens en bedoeld zijn om voor dit onderzoek een niveauverschil te kunnen vaststellen waar het maatregelenpakket op wordt gebaseerd. Niveau B is geen absoluut doelniveau of norm, maar is een hulpmiddel om te kunnen inschatten welke maatregelen in welke mate kunnen worden genomen bij een meerderheid van de bedrijven om op een hoger niveau voor de KPI's uit te komen, en wat dit uiteindelijk betekent voor de kosten.

Een belangrijk punt bij deze methode is ook dat het maatregelenpakket afgestemd is op het verschil tussen A en B. Voor de verschillende bedrijfstypen is het verschil tussen A en B niet steeds gelijk. Als we bijvoorbeeld kijken naar subsidie uit agrarisch natuurbeheer is het verschil tussen A en $B$ voor de bedrijven op veen aanmerkelijk groter ( $€$ 127/ha) dan voor intensieve bedrijven op zand en klei (€ 41/ha).

De niveaus in tabel 3.1 zijn gemiddelden van een groep bedrijven. De variatie binnen elke groep van bedrijven is groot. Binnen de groep bedrijven van niveau $B$ bevinden zich bijvoorbeeld ook bedrijven die op een of enkele indicatoren relatief ongunstig scoren (en dus een lage ranking kregen hiervoor), maar die dat compenseren door gunstig te scoren (dus een hoge ranking) op andere indicatoren. Er is in dit onderzoek dus niet gewerkt met drempelwaarden, omdat die niet beschikbaar zijn (zomer 2019).

Uit de structuurkenmerken die behoren bij niveau A en B voor de drie bedrijfstypen blijkt dat de bedrijven van niveau $A$ gemiddeld intensiever zijn dan de bedrijven die niveau $B$ bepalen. Met name voor het extensieve klei/zand-bedrijf en het veenbedrijf is de bedrijfsomvang ook behoorlijk verschillend tussen niveau $A$ en $B$. De intensieve bedrijven op klei/zand zijn groter qua aantal koeien en totale melkproductie van het bedrijf.

In bijlage 1 is meer informatie opgenomen over de bedrijfsopzet en bedrijfsvoering van de verschillende bedrijfstypen en de daarbij behorende gemiddelden voor niveau $A$ en $B$.

\subsubsection{Bedrijfstypen en indicatoren akkerbouw}

De analyse is gebaseerd op gegevens uit 2017. Dit was landelijk een relatief normaal jaar qua weersomstandigheden.

In tabel 3.2 zijn per bedrijfstype voor niveau A en B de gemiddelden voor bedrijfskenmerken en de score op de biodiversiteits-KPI's voor akkerbouw weergegeven. De in het onderzoek gebruikte bedrijven uit het Bedrijveninformatienet representeren 2091 akkerbouwbedrijven. In 2017 waren er in totaal 7372 akkerbouwbedrijven in Nederland (CBS, 2019). De in het onderzoek betrokken Informatienetbedrijven representeren daarmee $28 \%$ van het totaalaantal bedrijven. Dit percentage ligt lager dan bij melkvee. Dit komt door de keuze voor bedrijven met herkenbare bouwplannen (zie ook paragraaf 2.3). 
Tabel 3.2 Bedrijfskenmerken en score op biodiversiteits-KPI's voor twee akkerbouwbedrijfstypen voor niveau $A$ en $B$ (2017).

\begin{tabular}{|c|c|c|c|c|}
\hline & \multicolumn{2}{|c|}{$\begin{array}{l}\text { Consumptieaardappel- } \\
\text { bedrijven (klei) }\end{array}$} & \multicolumn{2}{|c|}{$\begin{array}{l}\text { Zetmeelaardappel- } \\
\text { bedrijven (zand) }\end{array}$} \\
\hline & A & B & A & B \\
\hline $\begin{array}{l}\text { Aantal akkerbouwbedrijven dat deze Informatienetbedrijven } \\
\text { vertegenwoordigt }\end{array}$ & 925 & 443 & 478 & 245 \\
\hline \multicolumn{5}{|l|}{ Informatienetbedrijven vertegenwoordigt (\%) } \\
\hline \multicolumn{5}{|l|}{ Bedrijfskenmerken } \\
\hline Cultuurgrond (ha) & 76 & 87 & 123 & 139 \\
\hline Consumptieaardappelen (\%) & 22 & 20 & 1 & 0 \\
\hline Granen (\%) & 34 & 42 & 18 & 32 \\
\hline Graszaad (\%) & 4 & 6 & 1 & 0 \\
\hline Uien (\%) & 11 & 5 & 2 & 0 \\
\hline Overig (\%) & 13 & 9 & 6 & 2 \\
\hline \multicolumn{5}{|l|}{ Score op biodiversiteit-KPI's } \\
\hline Percentage rustgewassen (\% van de oppervlakte) & 39 & 53 & 22 & 33 \\
\hline Percentage groenbemester (\% van de oppervlakte) & 34 & 43 & 28 & 41 \\
\hline Organischestofaanvoer ( $\mathrm{kg}$ effectieve organische stof per ha) & 2.435 & 2.761 & 2.346 & 2.429 \\
\hline $\mathrm{N}$-overschot (kg/ha) & 140 & 123 & 101 & 85 \\
\hline
\end{tabular}

Voor een globaal beeld van de bedrijfstypen is in tabel 3.2 ook een aantal kenmerken van de bedrijven weergegeven. Het areaal cultuurgrond weerspiegelt de gemiddelde oppervlakte van de bedrijven achter niveau A en $B$. De bedrijven die niveau $B$ vormen, blijken gemiddeld groter en hebben een iets minder intensief bouwplan (meer granen, minder rooivruchten). Voor beide bedrijfstypen geldt dat niveau B voor alle afzonderlijke KPI's gemiddeld beter scoort dan niveau A. Het gemiddelde zetmeelbedrijf scoort slechter op de KPI's dan een gemiddeld consumptieaardappelbedrijf.

\subsection{Maatregelenpakketten}

Zoals in paragraaf 2.4 is aangegeven, is een workshop met experts georganiseerd om tot een prioritering en concretisering van maatregelen te komen. De opdracht aan de experts was hierbij om te komen tot een integraal maatregelenpakket dat leidt tot een verbetering op alle KPI's voor een gegeven bedrijfstype.

\section{Resultaten workshop}

Het resultaat van de workshop bestond uit een prioritering van categorieën maatregelen en binnen elke categorie een prioritering van de afzonderlijke maatregelen om per bedrijfstype te komen van de gemiddelde score op niveau A tot de gemiddelde score op niveau B. De lijst van geprioriteerde maatregelen per bedrijfstype is in bijlage 4 opgenomen. Tevens is gevraagd of er maatregelen gemist werden. Dit gaf geen aanleiding tot grote aanpassingen.

Aan de bespreking van de maatregelen in de workshop ging een discussie over de gekozen bedrijfstypen en (scores op) KPI's vooraf. Hierdoor ontstond een zoveel mogelijk gemeenschappelijk startpunt. Voor de akkerbouw was een discussie over mogelijke KPI's voor dit onderzoek noodzakelijk omdat er nog geen biodiversiteitsmonitor voor de akkerbouw bestaat. Deze is in ontwikkeling. Het beeld achteraf bij het projectteam is dat de combinatie van de prioritering en de gevoerde discussie, 
o.a. over concretisering, een goede basis heeft gevormd voor het samenstellen van de maatregelenpakketten zonder in details te treden per maatregel.

De informatie die tijdens de workshop over niveau $A$ en $B$ is ingebracht, wijkt af van niveau $A$ en $B$ zoals die in dit rapport zijn gepresenteerd. Dit komt doordat in de bepaling van niveau $A$ en $B$ in eerste instantie voor $\mathrm{CO}_{2}$ alleen de indicator per $\mathrm{kg}$ melk was meegenomen en niet de combinatie van $\mathrm{CO}_{2}$ per kg melk en per ha. De richting van de gevraagde ontwikkeling is echter niet veranderd. Daarmee is de input voor de prioritering nog steeds bruikbaar voor het vaststellen van de maatregelenpakketten.

De experts vonden het prioriteren lastig omdat werd gevraagd om in één keer rekening te houden met zeven KPI's en omdat de uitvoering van sommige maatregelen behoorlijk locatiespecifiek kan zijn. Een aantal maatregelen vroeg ook nog om een nadere concretisering, zoals de maatregelen voor agrarisch natuurbeheer en kruidenrijk grasland. Kruidenrijk grasland kan op verschillende manieren worden ingevuld, variërend van een meer productiegerichte invulling met bijvoorbeeld klaver tot een kruidenrijk grasland dat het resultaat is van verschraling.

Ten slotte was er sprake van een leereffect ten aanzien van de werkwijze in de workshop en de KPI's. In de melkveehouderij vroeg de eerste ronde met het eerste bedrijfstype duidelijk de meeste tijd. De toelichting op de aanpak, uitleg en verduidelijking van de maatregelen waren hier het meeste nodig. De andere bedrijfstypen zijn mede vanwege de nog beschikbare tijd een stuk sneller doorlopen. Mogelijk zou een herhaling met het eerste bedrijfstype tot andere resultaten kunnen leiden. In de akkerbouw is klei uitgebreid doorlopen en zijn aan het eind verschillen met zandgronden expliciet gemaakt.

\subsubsection{Maatregelenpakketten melkveebedrijven}

Het is belangrijk om te benadrukken dat de gekozen maatregelenpakketten voorbeeldpakketten zijn. Het zijn pakketten waarvan wordt ingeschat dat bij toepassing ervan het niveau van de biodiversiteitsmonitor-KPI's zich ontwikkelt van de uitgangssituatie naar niveau B. Het betreft een 'gemiddeld' pakket voor een grote groep bedrijven. In specifieke bedrijfssituaties zullen andere pakketten beter passen om tot een betere score op de KPI's te komen.

Voor melkveebedrijven is uiteindelijk een set van achttien maatregelen samengesteld. Deze set is in tabel 3.3 opgenomen met een korte toelichting per maatregel. 
Tabel 3.3 Geselecteerde maatregelen voor melkveebedrijven met een kwalitatieve toelichting voor de invulling.

\section{Maatregel \\ I Bouwplan/grasland \\ 1 Meer gras en minder mais in het bouwplan \\ 2 Meer blijvend grasland binnen het bouwplan}

3 Grasland omzetten naar mengsel met klaver en bijvoorbeeld smalle weegbree

\section{Waterpeil/beheermaatregelen}

4 Hoger waterpeil

5 Onderwaterdrainage met peilbeheer

III Natuurbeheermaatregelen

6 Randenbeheer langs alle snijmaispercelen

7 Slootkantenbeheer

8 Kruidenrijk grasland met veel soorten door verschraling

9 Grasland plasdras

10 Uitstel maaidatum grasland

11 Erfvogels stimuleren IV Aanpassingen in bedrijfsvoering

12 Meer weidegang

13 Optimalisatie bemesting

14 Lichte machines en lage bandenspanning

15 Optimalisatie voeding

16 Levensduur verhogen

\section{Toelichting concrete invulling maatregel}

Mais wordt vervangen door grasland.

Dit betekent minder herinzaai en meer aandacht voor graslandbeheer zodat het grasland ook langer mee kan (bijvoorbeeld extra doorzaai). De melkveehouder zorgt voor kennisontwikkeling, bijvoorbeeld door het volgen van een cursus of het raadplegen van een adviseur.

Er wordt uitgegaan van een graslandmengsel met klaver en bijvoorbeeld smalle weegbree. Het mengsel wordt geleidelijk geïntroduceerd bij reguliere herinzaai (introductie over tien jaar).

Het waterpeil wordt gemiddeld met $10 \mathrm{~cm}$ verhoogd.

Onderwaterdrainage wordt toegepast.

$\mathrm{Er}$ is uitgegaan van een rand van één meter die wordt ingezaaid met een kruiden-/bloemenmengsel.

Voor veengronden wordt gewerkt met een rand van drie meter langs de sloot die niet wordt bemest. De percelen worden afgerasterd en er worden drinkbakken geplaatst.

Een rustperiode in het voorjaar wordt gecombineerd met minder bemesten en minimaal één keer maaien. De maatregel is gebaseerd op A01.01.05 (website Bij12).

Een rustperiode in het voorjaar. De percelen worden plasdras gezet in het voorjaar. De maatregel is gebaseerd op A01.01.03 (website bij12).

Voor deze maatregel is gewerkt met een rustperiode van 1 april tot 1 juni. De maatregel is gebaseerd op A01.01.01 (website Bij12). Met name nestkasten aanbrengen.

Bij bedrijven die in de uitgangssituatie nog niet weiden, moeten een afrastering en drinkbakken worden geplaatst. Met optimalisatie wordt het maken en uitvoeren van een gedetailleerd bemestingsplan bedoeld. Het resultaat is het preciezer bemesten op basis van behoefte en gebruik (bijvoorbeeld maaien/weiden) op perceelniveau en daar waar mogelijk sturen met dikkere of dunnere mest. De melkveehouder verkrijgt extra kennis door bijvoorbeeld een cursus te volgen of een adviseur te raadplegen. Om bodemverdichting te vermijden worden lichtere (kleinere) machines en drukwisselsystemen ingezet.

Het betreft het maken en uitvoeren van een plan voor graslandmanagement. Er komt meer focus op het voeren op eiwitnorm en het verbeteren van de voerefficiëntie. De melkveehouder verkrijgt extra kennis door een cursus te volgen of een adviseur te raadplegen.

Het betreft investeren in het koecomfort in de stal (bijvoorbeeld ligbedden, rubber op de (rooster-)vloer en minder jongvee). Het investeren in kennis en advies is meegenomen (o.a. in samenwerking met de dierenarts).

\section{Aanvullend klimaat}

17 Zonne-energie Zonnepanelen plaatsen.

18 Krachtvoer met lagere $\mathrm{CO}_{2}$-footprint 
Het is belangrijk om te benadrukken dat het uiteindelijk gaat om het totale pakket van maatregelen gericht op alle KPI's. Niet alle afzonderlijke maatregelen werken gunstig op alle KPI's. Dit betekent dat ongunstige effecten van bepaalde maatregelen weer door andere maatregelen moeten worden gecompenseerd. Daarmee is een samenhangend maatregelenpakket ontstaan. Per categorie volgt een korte toelichting op de achtergrond van de maatregelen en de relatie met de KPI's.

I. Bouwplan/grasland: meer gras in het bouwplan levert met name een bijdrage aan het verhogen van het aandeel eigen eiwit van het bedrijf. Meer gras in het bouwplan kan leiden tot een hoger $\mathrm{N}$-overschot. Belangrijk is dat de bemesting optimaal wordt uitgevoerd. Meer gras in het rantsoen kan leiden tot hogere broeikasgasemissies en ook tot meer ammoniakemissie. Dit kan/moet gecompenseerd worden via het nog aan te kopen voer en/of door meer weidegang toe te passen. De overgang naar een ander grasmengsel met klaver (en bijvoorbeeld smalle weegbree en minimaal drie grassoorten) draagt bij aan de KPI kruidenrijk grasland, en doordat klaver stikstof bindt, kan bovendien worden bespaard op kunstmest. Meer blijvend grasland is een maatregel die een-op-een is gekoppeld aan een van de KPI's.

II. Waterpeil/beheermaatregelen: deze maatregelen worden alleen op het veenbedrijf genomen. Het betreft een verhoging van het waterpeil en onderwaterdrainage met peilbeheer. Beide maatregelen zijn gericht op het voorkomen van bodemdaling en broeikasgasemissies vanuit het veen.

III. Natuurbeheermaatregelen: deze maatregelen zijn nodig om te voldoen aan de KPI's voor kruidenrijk grasland en natuur en landschap. De exacte invulling hangt sterk af van de lokale omstandigheden en mogelijkheden. In het ene gebied zullen lijnelementen beter passen en in het andere gebied vlakelementen. De gekozen maatregelenpakketten zijn dan ook voorbeelden. Ze zijn zodanig ingevuld dat het verschil in niveau tussen A en B wordt overbrugd.

IV. Aanpassingen in bedrijfsvoering: het gaat hier onder andere over een aantal optimalisatiemaatregelen, met name rond voeding, bemesting en graslandmanagement. Die maken het mogelijk om bijvoorbeeld met minder kunstmest te volstaan en ook de voerefficiëntie te verhogen. Dit draagt bij aan een lager bodemoverschot, een lagere broeikasgasemissie en een lagere ammoniakemissie. De extra weidegang maakt een betere benutting van eiwit van het eigen bedrijf mogelijk en draagt bij aan een lagere ammoniakemissie.

V. Aanvullend klimaat: dit zijn maatregelen om de broeikasgasemissie te reduceren. Het plaatsen van zonnepanelen om zelf de energie voor eigen gebruik op te wekken draagt bij aan de verlaging van de broeikasgasemissie van het melkveebedrijf. Het aankopen van krachtvoer met een lage footprint draagt direct bij aan een lagere broeikasgasemissie voor het hele bedrijf.

Enkele specifieke maatregelen die in de expertworkshop een (vrij) hoge prioriteit hadden gekregen, zijn uiteindelijk niet opgenomen in de maatregelenpakketten omdat ze moeilijk inpasbaar zijn, wettelijk al verplicht zijn of nog niet praktijkrijp zijn binnen een periode van vijf jaar, of waarvoor veel additionele databewerkingen nodig zijn. Voor melkvee waren dit de volgende maatregelen:

- Toepassen van een groenbemester na snijmais: op zandgrond is dit al verplicht, op kleigrond worden groenbemesters beperkt toegepast. Aanvullend geraadpleegde experts hebben aangegeven dat deze maatregel op kleigrond moeilijk inpasbaar is. Dit geldt met name voor de wat zwaardere gronden die bij voorkeur in het najaar bewerkt worden;

- Niet berijden van percelen onder natte omstandigheden: de bedrijven achter de gemiddelden van niveau $A$ en niveau $B$ hebben gemiddeld ruim negen maanden mestopslag. Dit betekent dat er in principe al voldoende flexibiliteit is in het tijdstip van uitrijden van mest. Het is niet reëel om hier nog een aanvullend effect van te verwachten;

- Scheiden van mest in dikke en dunne fractie: dit is meer iets voor inpassing op de langere termijn. Als je de maatregel goed uit wilt voeren, vraagt dit relatief grote investeringen in apparatuur, de stal en mestopslag. Overigens wordt deze maatregel voor de lange termijn als perspectiefvol gezien voor onder andere het verlagen van de ammoniakemissie, maar ook voor het terugdringen van de methaanemissie; 
- Extensiveren: deze maatregel kwam in beeld voor het intensieve zand/klei-bedrijf. Het streven was om maatregelen te nemen binnen de huidige bedrijfsstructuur. Als er veel grond bij moet, dan is het niet waarschijnlijk dat dit binnen vijf jaar gerealiseerd kan worden. Als het intensieve bedrijf terug zou moeten naar $20.000 \mathrm{~kg}$ melk per hectare (suggestie uit de expertworkshop), dan moet er dertien hectare grond bij. Bovendien roept het aanvullende vragen op of er bijvoorbeeld grond beschikbaar is in een regio en wat exact het effect is van extensivering op de indicatoren. Zolang het bedrijf nog niet zelfvoorzienend is in ruwvoer, is het effect op de KPI's beperkt. In overleg met de begeleidingsgroep is besloten om deze maatregel niet te nemen;

- Samenwerken met akkerbouw voor voerteelt: deze maatregel heeft naar verwachting een beperkt effect op de combinatie van KPI's uit de biodiversiteitsmonitor. Het meeste effect is te verwachten voor de KPI 'aandeel eiwit van eigen bedrijf' als daarin ook de buurtcontracten worden meegenomen (voer binnen een straal van $20 \mathrm{~km}$ geteeld telt dan mee). Deze data zijn echter niet beschikbaar in de gebruikte dataset.

De maatregelen zijn vervolgens nader geconcretiseerd en gekwantificeerd (tabel 3.4). Zoals hiervoor aangegeven is de concrete invulling gebaseerd op de input vanuit de expertworkshop en op de verschillen in bedrijfsvoering tussen $A$ en $B$.

Tabel 3.4 Kwantificering maatregelen voor melkveebedrijven ten opzichte van niveau A.

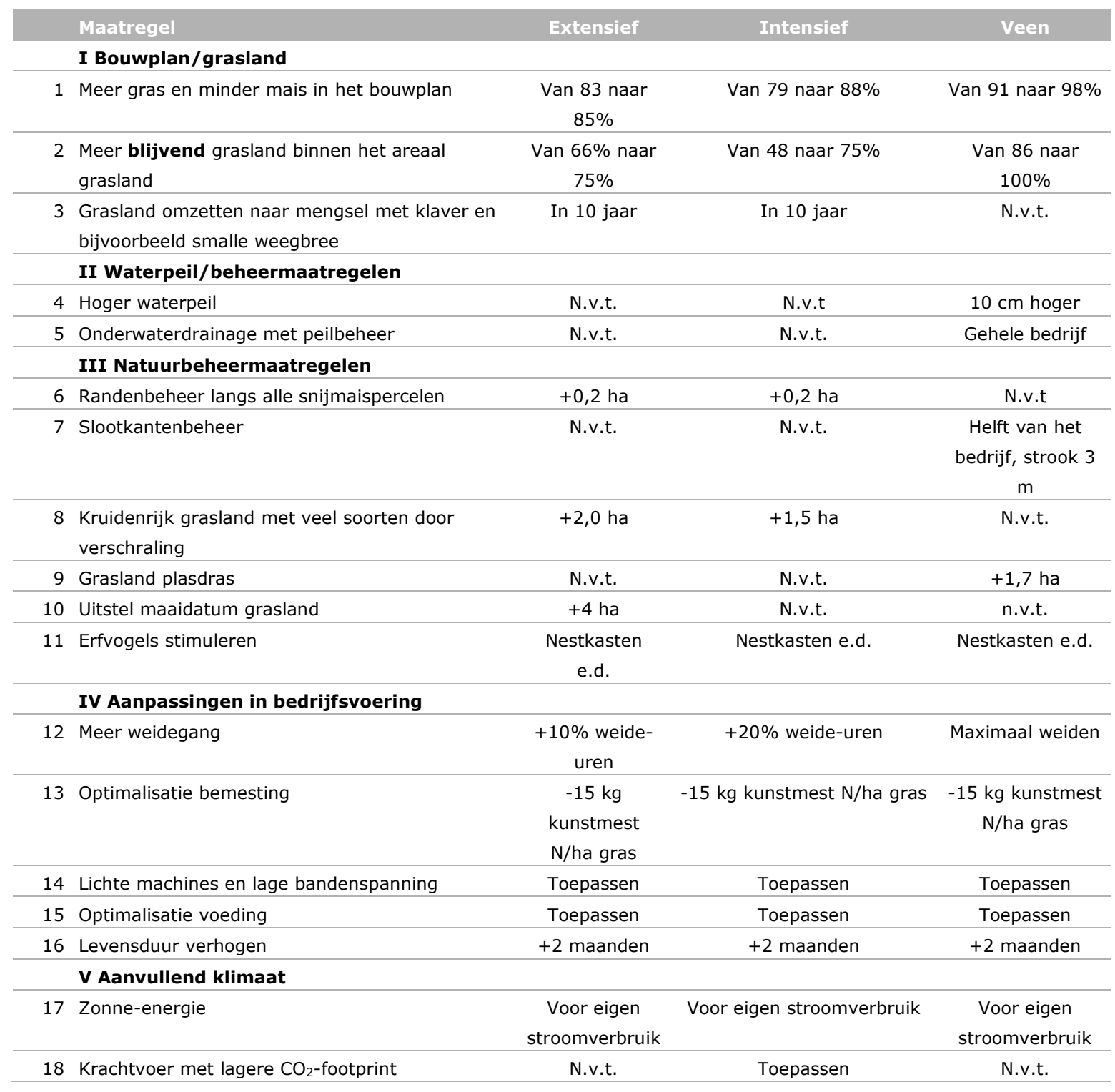


Toelichting rond de kwantificering van maatregelen per categorie:

Bouwplan/grasland. De toename in het areaal grasland is afgeleid van het verschil tussen niveau $A$ en $\mathrm{B}$. Bij het verhogen van het areaal blijvend grasland is ook naar niveau B gekeken. Daar lag het aandeel blijvend grasland van de totale oppervlakte grasland op de zand/klei-bedrijven zowel voor de intensieve als de extensieve bedrijven rond de $90 \%$. Dit is een groot verschil met de $66 \%$ en $48 \%$ in de uitgangssituatie. Daarom is nader gekeken naar de achtergrond van het verschil. Dit wordt mede veroorzaakt doordat bij niveau $B$ relatief meer bedrijven op kleigrond zitten en minder op zand. Mede op basis van de input van de reviewers van de maatregelenpakketten is de maatregel minder ver doorgevoerd dan het verschil tussen A en B. Met name op zandgrond is het moeilijk om bijvoorbeeld bij droogte de kwaliteit van het grassenbestand voldoende op peil te houden voor een goede voerproductie en is soms herinzaai of wisselbouw gewenst. Dit geeft ook ruimte om snijmais met grasland te wisselen en daarmee continuteelt van snijmais te vermijden, en zo blijft er ook ruimte voor uitruil met akkerbouw. De maatregel komt uiteindelijk uit op 75\% van het grasland als blijvend grasland (Eekeren, 2016). Het grasland op het bedrijf wordt geleidelijk aan omgezet in een variant met productiegericht kruidenrijk grasland bestaande uit meerdere grassoorten, klaver en bijvoorbeeld smalle weegbree. Dit betekent dat niveau B voor deze indicator niet wordt gehaald.

Waterpeil/beheermaatregelen. Deze maatregelen worden alleen voor het veenbedrijf genomen en worden gezien als noodzakelijk om de bodemdaling en emissies te verminderen.

Natuurbeheermaatregelen. De opgenomen maatregelen zijn nadrukkelijk voorbeelden. De exacte invulling zal sterk afhangen van de lokale omstandigheden en kan ook afhangen van de voorkeuren van de boer. De omvang van de maatregelen is bepaald door het verschil in ontvangen beheervergoeding tussen niveau A en niveau $B$. Met het totaal aan maatregelen wordt dit gat ingevuld.

Aanpassingen bedrijfsvoering. Deze maatregelen zijn vooral van belang om de score op KPI's als Noverschot per ha, ammoniakemissie per hectare en CO2-emissies te verbeteren. Het gaat hier vooral om managementmaatregelen. Voor alle drie de bedrijfstypen zien we een verschil tussen niveau $A$ en $B$ : de bedrijven met niveau $B$ weiden duidelijk meer. Voor het extensieve bedrijf is het verschil tussen $A$ en $B$ als maatregel opgenomen. Voor het intensieve bedrijf was het verschil in weidedagen vrij groot (40\% meer weidedagen). Dat wordt waarschijnlijk mede veroorzaakt doordat de bedrijven uit de B-groep meer blijvend grasland hebben, zoals hiervoor al is beschreven. De vraag is dan ook of fors meer weiden voor de A-groep haalbaar is. Daarom is gekozen voor $20 \%$ meer weidegang. Een tweede punt hierbij is dat een deel van de bedrijven uit de A-groep in de uitgangsituatie helemaal niet beweidt. Een deel zal dit bijvoorbeeld ook niet kunnen vanwege een te kleine huiskavel. Dit illustreert nog eens dat de uiteindelijke invulling van maatregelen per individueel bedrijf zal verschillen. Bedrijven die niet (meer) kunnen weiden, zullen dan andere maatregelen moeten nemen om de gewenste vooruitgang op de KPI's te realiseren. Voor ammoniakemissie zal dit bijvoorbeeld kunnen betekenen dat technische maatregelen moeten worden genomen, zoals het installeren van luchtwassers.

Bij de maatregel 'optimalisatie bemesting' is een verlaging van de kunstmestgift opgenomen. Dit was een maatregel die naar voren kwam uit de expertworkshop. Het verschil in kunstmestgift tussen het gemiddelde van niveau A en B was voor het extensieve klei/zand-bedrijf en het veenbedrijf vrij klein. Voor het intensieve klei/zand-bedrijf was het verschil tussen de gemiddelden $40 \mathrm{~kg}$ kunstmeststikstof per ha. Dit verschil bleek geheel te verklaren uit het verschil in stikstofgebruiksruimte tussen de achterliggende bedrijven en is dus geen goede indicatie voor de te nemen maatregel. Uiteindelijk is gekozen voor een $\mathrm{N}$-kunstmestverlaging van $15 \mathrm{~kg}$. In combinatie met een betere benutting van de dierlijke mest en de geleidelijke introductie van klaver wordt dit haalbaar geacht zonder opbrengstderving.

Achter de optimalisatie van de voeding zitten verschillende maatregelen, o.a. verbeteren van het graslandmanagement en meer aandacht voor de voerefficiency in de rantsoenen, bijvoorbeeld in de vorm van meer op de eiwitnorm voeren. Dit vraagt een investering in kennis en advies en bijvoorbeeld meer voeranalyses om beter te kunnen sturen. Het werken met lichtere machines op het land betekent vooral meer uren werk en/of hogere loonwerkkosten. Hierbij wordt de verwachting uitgesproken dat dit ook tot betere opbrengsten leidt, maar hier waren geen goede bronnen voor beschikbaar. Levensduurverhoging is een belangrijke maatregel omdat die integraal doorwerkt op bijvoorbeeld broeikasgas- en ammoniakemissie. Het is een van de doelstellingen van de Duurzame 
Zuivelketen, maar tot nu toe wordt op dit vlak nog betrekkelijk weinig vooruitgang geboekt (Doornewaard et al., 2018). Dit geeft aan dat er wel duidelijk maatregelen genomen moeten worden om hier vooruitgang te bereiken. Overigens is de verwachting dat de huidige invulling van het fosfaatrechtenstelsel ook al een prikkel is om tot een langere levensduur te komen.

Aanvullend klimaat. Het leggen van zonnepanelen voor het eigen energieverbruik is een concrete maatregel die geen verdere impact heeft op de bedrijfsvoering. Voor het intensieve bedrijf zorgt het hogere aandeel gras in het rantsoen voor een toename van de broeikasgasemissie. Dit moet gecompenseerd worden door krachtvoer met een lagere emissie.

Een belangrijk punt bij de samenstelling van de maatregelenpakketten is dat in dit onderzoek vanuit gemiddelde bedrijven per bedrijfstype wordt gerekend en dat we ervan uitgaan dat maatregelen ook in stapjes kunnen worden genomen en haalbaar zijn in een periode van circa vijf jaar. In de praktijk kan het pakket per bedrijf anders zijn door verschillen in locatie en bedrijfsvoering. In de cijfers is duidelijk zichtbaar dat sommige wettelijke normen (bijvoorbeeld de derogatie-eis voor het aandeel grasland en de gebruiksnormen voor dierlijke mest en kunstmest) of vereisten voor premies (zoals de definitie van weidegang (120 dagen per jaar, 6 uur per dag)) sterk bepalend zijn voor de huidige score voor de bedrijfsopzet.

\subsubsection{Maatregelenpakketten akkerbouwbedrijven}

Voor akkerbouw resulteerden de uitgevoerde stappen in een lijst van veertien maatregelen (tabel 3.5) met een korte toelichting.

Tabel 3.5 Geselecteerde maatregelen voor akkerbouwbedrijven met kwalitatieve toelichting voor de invulling.

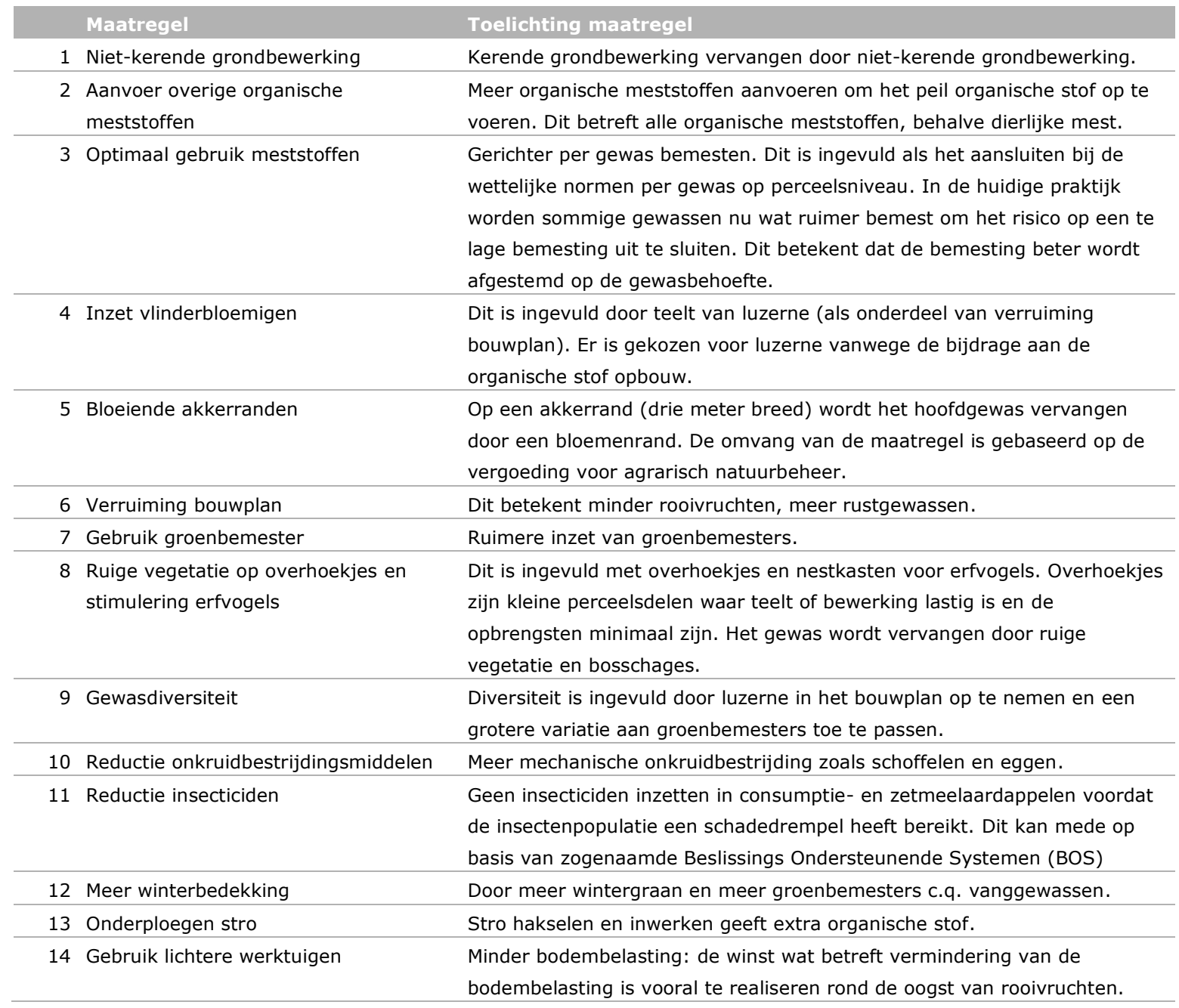


Aanname is dat met niet-kerende grondbewerking ${ }^{3}$ minder organische stof wordt afgebroken en dat dat een gunstige invloed heeft op de OS-balans en de beschikbaarheid van water en lucht voor de plant, en daarmee op de opname van stikstof, de robuustheid van het gewas en het gebruik van gewasbeschermingsmiddelen. Aan de andere kant is het de vraag of je met evenveel herbiciden toekunt.

Een groot aantal maatregelen is gericht op (organische stof in) de bodem. Een hogere OS-toevoer heeft een gunstige invloed op de OS-balans en de beschikbaarheid van water en lucht voor de plant, en daarmee op de opname van stikstof, de robuustheid van het gewas en het gebruik van gewasbeschermingsmiddelen. Aan de andere kant wordt er wel meer organisch gebonden $\mathrm{N}$ toegevoegd. Het is de vraag of dit volledig gecompenseerd zal worden met minder stikstoftoediening vanuit andere bronnen. Voor aanvoer van organische stof is de aanname dat er voldoende aanbod is van voldoende kwaliteit. De inzet van groenbemesters resulteert in een hogere aanvoer van organische stof, en ook het inwerken van stro levert hier een bijdrage aan. De verruiming van het bouwplan is gericht op een hoger aandeel rustgewassen, wat de bodemkwaliteit ten goede komt. Om de bodemkwaliteit verder te verbeteren wordt bij de oogst van aardappelen en suikerbieten de belasting van de bodem verminderd door bunkerrooiers toe te passen en deze telkens op de kopakker te lossen.

Het stikstofoverschot moet met name afnemen door een optimalisatie van de bemesting.

Het gebruik van gewasbeschermingsmiddelen moet afnemen door onkruiden mechanisch aan te pakken, o.a. door te schoffelen en onkruideggen. Belangrijk hierbij is wel om op de risico's van het vernielen van vogelnesten te letten. Voor insecticiden wordt ingezet op intensiever scouten van het gewas en het kiezen van middelen met het juiste werkingsspectrum, waarbij deze middelen pas moeten worden ingezet als dit nodig is (reduceren preventieve bespuitingen).

De natuurbeheermaatregelen worden ingevuld door de aanleg van bloeiende akkerranden en ruige vegetatie in overhoekjes.

In tabel 3.6 wordt een kwantitatieve invulling gegeven van de maatregelen.

3 Minder diepe grondbewerking met ecoploeg, schijveneg, cultivator e.d. Bij niet-kerende grondbewerking wordt de bodem niet dieper dan twaalf centimeter bewerkt. Men vermengt gewasresten dus alleen oppervlakkig met de bodem. Indien nodig wordt de ondergrond losgemaakt (gewoeld) zonder deze te vermengen met andere bodemlagen. Door de bodem niet te keren en minder intensief te bewerken, spaart men het bodemleven. Ook is er minder bodemverdichting door bijvoorbeeld de banden in de ploegvoor. 
Tabel 3.6 Kwantificering maatregelen voor consumptieaardappelbedrijven op kleigrond en zetmeelaardappelbedrijven. De inzet van de maatregelen is afhankelijk van het niveau van de $A$ groep.

\begin{tabular}{|c|c|c|c|}
\hline & Maatregel & $\begin{array}{l}\text { Consumptieaardappel } \\
\text {-bedrijven (klei) }\end{array}$ & $\begin{array}{l}\text { Zetmeelaardappel- } \\
\text { bedrijven (zand) }\end{array}$ \\
\hline 1 & Niet-kerende grondbewerking (\% van oppervlakte) & Van $5 \%$ naar $10 \%$ & Van $5 \%$ naar $10 \%$ \\
\hline 3 & Optimaal gebruik meststoffen & Toepassen & Toepassen \\
\hline 5 & Bloeiende akkerranden (\% oppervlakte) & Van $0,1 \%$ naar $1,1 \%$ & Van $0,1 \%$ naar $1,1 \%$ \\
\hline \multirow[t]{8}{*}{6} & Verruiming bouwplan & & \\
\hline & Luzerne & Van $0,0 \%$ naar $1,0 \%$ & Van $0,0 \%$ naar $1,0 \%$ \\
\hline & Granen & Van $33,7 \%$ naar $42,2 \%$ & Van $18,0 \%$ naar $25,0 \%$ \\
\hline & Pootaardappelen & Blijft 0,5\% & Van $3,7 \%$ naar $3,2 \%$ \\
\hline & Zetmeelaardappelen & Blijft 0,0\% & Van $43,7 \%$ naar $37,1 \%$ \\
\hline & Uien & Van $11,5 \%$ naar $6,5 \%$ & Blijft $1,6 \%$ \\
\hline & Suikerbieten & Van $15,3 \%$ naar $12,8 \%$ & Van $24,3 \%$ naar $22,8 \%$ \\
\hline & Overige gewassen & Van $12,5 \%$ naar $11,5 \%$ & Van $4,6 \%$ naar $4,1 \%$ \\
\hline 7 & Gebruik groenbemester (\% van oppervlakte) & Van $34 \%$ naar $43 \%$ & Van $28 \%$ naar $38 \%$ \\
\hline 8 & $\begin{array}{l}\text { Ruige vegetatie op overhoekjes en stimulering erfvogels (\% } \\
\text { oppervlakte) }\end{array}$ & $+0,5 \%$ & $+0,5 \%$ \\
\hline 9 & Gewasdiversiteit (aantal gewassen) & Van 7 naar 8 & Van 7 naar 8 \\
\hline
\end{tabular}

Bij akkerbouw ligt de nadruk bij de invulling van de maatregelen meer op de toepassing van de maatregelen binnen de gehele groep van de achterliggende bedrijven. Binnen de huidige groep is de aanname dat nu op 5\% van het areaal niet-kerende grondbewerking wordt toegepast; in de nieuwe situatie is dat $10 \%$.

Ook bij akkerbouw geldt dat de natuurbeheermaatregelen zoals die hier zijn ingevuld een voorbeeld zijn. Hier zijn ook andere maatregelen mogelijk.

De inschatting is dat niveau B met dit pakket van maatregelen geheel of vrijwel geheel behaald zal worden voor de gekozen KPI's. Om het aandeel rustgewassen op het gewenste niveau te brengen, is een ingrijpende verandering van het bouwplan aangebracht. De sterke vermindering van het aandeel consumptieaardappelen, zetmeelaardappelen, uien en suikerbieten kan eveneens grote gevolgen hebben voor de verwerkende industrie en voor de exportpositie van Nederland. De effecten hiervan zijn in dit onderzoek niet in beeld gebracht.

\subsection{Kosten van de maatregelenpakketten}

\subsubsection{Kosten voor melkveebedrijven}

In tabel 3.7 is de basis voor de berekening van de kosten weergegeven. 
Tabel 3.7 Toelichting kosten per maatregel voor melkveebedrijven.

\section{Maatregel Toelichting berekening meerkosten}

Bouwplan/grasland

1 Meer gras en minder mais in het bouwplan

Gras heeft een lagere kVEM-opbrengst dan snijmais. Het verschil in opbrengst is gebaseerd op Informatienetgegevens per bedrijfstype (circa 8000 kVEM per ha). Deze lagere opbrengst wordt gecompenseerd door voeraankopen. Dit gebeurt voor een deel in de vorm van krachtvoer om de melkproductie per koe op peil te houden, prijzen op basis van KWIN (2018).

2 Meer blijvend grasland binnen het Meer blijvend grasland resulteert in minder herinzaai, maar ook in meer bouwplan handelingen voor graslandbeheer, bijvoorbeeld extra doorzaai. De veehouder investeert in kennis en advies ( $€ 250$ per jaar). Er is gerekend met een opbrengstderving van $10 \%$ voor het areaal dat van tijdelijk grasland naar blijvend grasland gaat (Grondig, 2011). Prijzen en loonwerktarieven op basis van KWIN.

3 Grasland omzetten naar Het graszaad voor kruidenrijk productiegericht grasland is duurder (mede op productiegericht kruidenrijk mengsel met klaver en bijvoorbeeld smalle basis van De Wit et al. 2017). Er is gerekend met een opbrengstderving van $1,7 \%$ (Geerts, 2007). weegbree Waterpeil/beheermaatregelen

4 Hoger waterpeil De graslandopbrengst gaat omlaag, gebaseerd op een gemiddeld effect van het westelijk en noordelijk veenweidegebied à $€$ 105/ha (Natuur en Milieufederaties, 2014).

5 Onderwaterdrainage met peilbeheer Er is gerekend met een investering van $€ 1750$ /ha in onderwaterdrainage en peilbeheer voor het bedrijfstype veen (Kennisprogramma Bodemdaling, 2018, Deltaplan Agrarisch Waterbeheer).

Natuurbeheermaatregelen

6 Randenbeheer langs alle snijmaispercelen

De opbrengstderving van de ingezaaide oppervlakte is meegenomen. Er zijn geen alternatieve opbrengsten.

7 Slootkantenbeheer $\mathrm{Er}$ is gerekend met de opbrengstderving van randen van één meter voor veen. Verder is de investering in afrastering en drinkbakken meegenomen.

8 Kruidenrijk grasland met veel soorten Er wordt uitgegaan van een rustperiode in het voorjaar, minder bemesten en door verschraling minimaal één keer maaien, gebaseerd op de beheervergoeding van Bij12, $€ 1277 /$ ha.

9 Grasland plasdras Er wordt uitgegaan van een rustperiode in het voorjaar (15 februari tot 1 juli), plasdras, gebaseerd op de beheervergoeding van Bij12, € 2091/ha.

10 Uitstel maaidatum grasland De kosten zijn gebaseerd op een rustperiode van 1 april tot 1 juni. De kosten zijn gebaseerd op de beheervergoeding van Bij12, $€ 275 /$ ha.

11 Stimuleren erfvogels $\mathrm{Er}$ is uitgegaan van een eenmalige kostenpost van $€ 500$ voor nestkasten e.d. Aanpassingen in bedrijfsvoering

12 Meer weidegang

Voor bedrijven die in de uitgangssituatie nog niet weiden, zijn investeringen in afrastering en drinkbakken meegenomen. Verder is extra weidegang kostenneutraal (o.a. op basis van Reijs 2013).

13 Optimalisatie bemesting De bemesting wordt vooral geoptimaliseerd door te investeren in kennis en advies, wat ook leidt tot extra arbeidsinzet van de melkveehouder. Dit is samen ingeschat op $€ 2500$. De besparing op kunstmest is bepaald op basis van $€ 0,91$ per $\mathrm{kg}$.

14 Lichte machines en lage bandenspanning Lichtere/kleinere machines zijn goedkoper. Het zal wel langer duren om hetzelfde werk uit te voeren. De inschatting is dat de extra kosten voor arbeid en loonwerk tot 5\% hogere kosten leiden.

15 Optimalisatie voeding Dit wordt vooral gerealiseerd door te investeren in kennis en advies. $\mathrm{Er}$ is gerekend met 24 uur per jaar voor het inhuren van een adviseur, en extra uren van de melkveehouder, met name gericht op beter voer- en graslandmanagement. Dit levert een besparing van 5\% op de krachtvoerkosten op. De potentiële winst is mede afgeleid van Schooten (2013). 
Maatregel

16 Verhogen levensduur
Toelichting berekening meerkosten

Er is uitgegaan van een investering in koecomfort in de stal ( $€ 300$ per koe in ligbedden, rubber op de (rooster-)vloer, minder jongvee aanhouden). Daarnaast is uitgegaan van een investering in kennis en advies. Naast het advies van maatregel 15 nog vier uur per kwartaal extra aan dierenartskosten en bijbehorende uren van de melkveehouder. De meeropbrengsten worden hoog ingeschat tot $€ 0,03$ à $€ 0,04$ per kg melk bij één jaar levensverlenging (Booij, 2014). De levensverlenging is hier lager ingeschat (twee maanden). De aanname is dat de invoering van fosfaatrechten hier al een sterke prikkel voor vormt. Het gaat hier om aanvullende levensduurverhoging. Het uitgangspunt is dat dit kostenneutraal is (zie ook Zijlstra 2013).

\section{Aanvullend klimaat}

17 Zonne-energie

18 Krachtvoer met lagere $\mathrm{CO}_{2}$-footprint
Dit is ingevuld door het plaatsen van zonnepanelen. Het uitgangspunt is een verdubbeling van het aandeel bedrijven met zonnepanelen in de groep van $20 \%$ naar 40\%. Het rendement is gebaseerd op Spruijt 2016 en Wemmenhove 2019. Krachtvoer met een lagere $\mathrm{CO}_{2}$-footprint aankopen. De lagere footprint kan door sojaschroot in het mengvoer te vervangen door lupinen of raap. Lupinen zijn niet ruim beschikbaar en met raap gaat fosfaat weer omhoog (Lieftink, 2019). Er is gerekend met een meerprijs van 5\% voor krachtvoer met een lagere footprint. (mede afgeleid van Šebek 2016)

De berekening van de meerkosten leidt tot tabel 3.8. Voor melkvee zijn de meerkosten toegerekend aan de melkproductie.

Tabel 3.8 Meerkosten per maatregel per bedrijfstype op jaarbasis (in $€ / 100 \mathrm{~kg}$ melk).

\begin{tabular}{|c|c|c|c|c|}
\hline & Maatregel & Extensief & Intensief & Veen \\
\hline \multicolumn{5}{|c|}{ Bouwplan/grasland } \\
\hline 1 & Meer gras en minder mais in het bouwplan & 0,20 & 0,55 & 0,58 \\
\hline 2 & Meer blijvend grasland binnen het bouwplan & 0,11 & 0,19 & 0,16 \\
\hline 3 & $\begin{array}{l}\text { Grasland omzetten naar mengsel met klaver en } \\
\text { bijvoorbeeld smalle weegbree }\end{array}$ & 0,51 & 0,36 & 0,00 \\
\hline \multicolumn{5}{|c|}{ Waterpeil/beheermaatregelen } \\
\hline 4 & Hoger waterpeil & & & 0,48 \\
\hline \multirow[t]{2}{*}{5} & Onderwaterdrainage met peilbeheer & & & 0,40 \\
\hline & \multicolumn{4}{|l|}{ Natuurbeheermaatregelen } \\
\hline 6 & Randenbeheer langs alle snijmaispercelen & 0,06 & 0,04 & \\
\hline 7 & Slootkantenbeheer & & & 0,48 \\
\hline 8 & $\begin{array}{l}\text { Kruidenrijk grasland met veel soorten op basis } \\
\text { van verschraling }\end{array}$ & 0,24 & 0,13 & 0,00 \\
\hline 9 & Grasland plasdras & & & 0,29 \\
\hline 10 & Uitstel maaidatum grasland & 0,10 & & \\
\hline \multirow[t]{2}{*}{11} & Stimuleren erfvogels & 0,01 & 0,00 & 0,01 \\
\hline & Aanpassingen in bedrijfsvoering & & & \\
\hline 12 & Meer weidegang & 0,00 & 0,05 & 0,00 \\
\hline 13 & Optimalisatie bemesting & 0,17 & 0,12 & 0,16 \\
\hline 14 & Lichte machines en lage bandenspanning & 0,74 & 0,63 & 0,74 \\
\hline 15 & Optimalisatie voeding & $-0,10$ & $-0,18$ & $-0,14$ \\
\hline \multirow[t]{2}{*}{16} & Verhogen levensduur & 0,00 & 0,00 & 0,00 \\
\hline & Aanvullend klimaat & & & \\
\hline 17 & Zonne-energie & $-0,08$ & $-0,08$ & $-0,08$ \\
\hline \multirow[t]{2}{*}{18} & Krachtvoer met lagere $\mathrm{CO}_{2}$-footprint & & 0,39 & \\
\hline & Totaal & 1,95 & 2,18 & 3,08 \\
\hline
\end{tabular}

Samengevat zijn de meerkosten voor melkveebedrijven per bedrijfstype en per categorie maatregelen in figuur 3.1 weergegeven. 


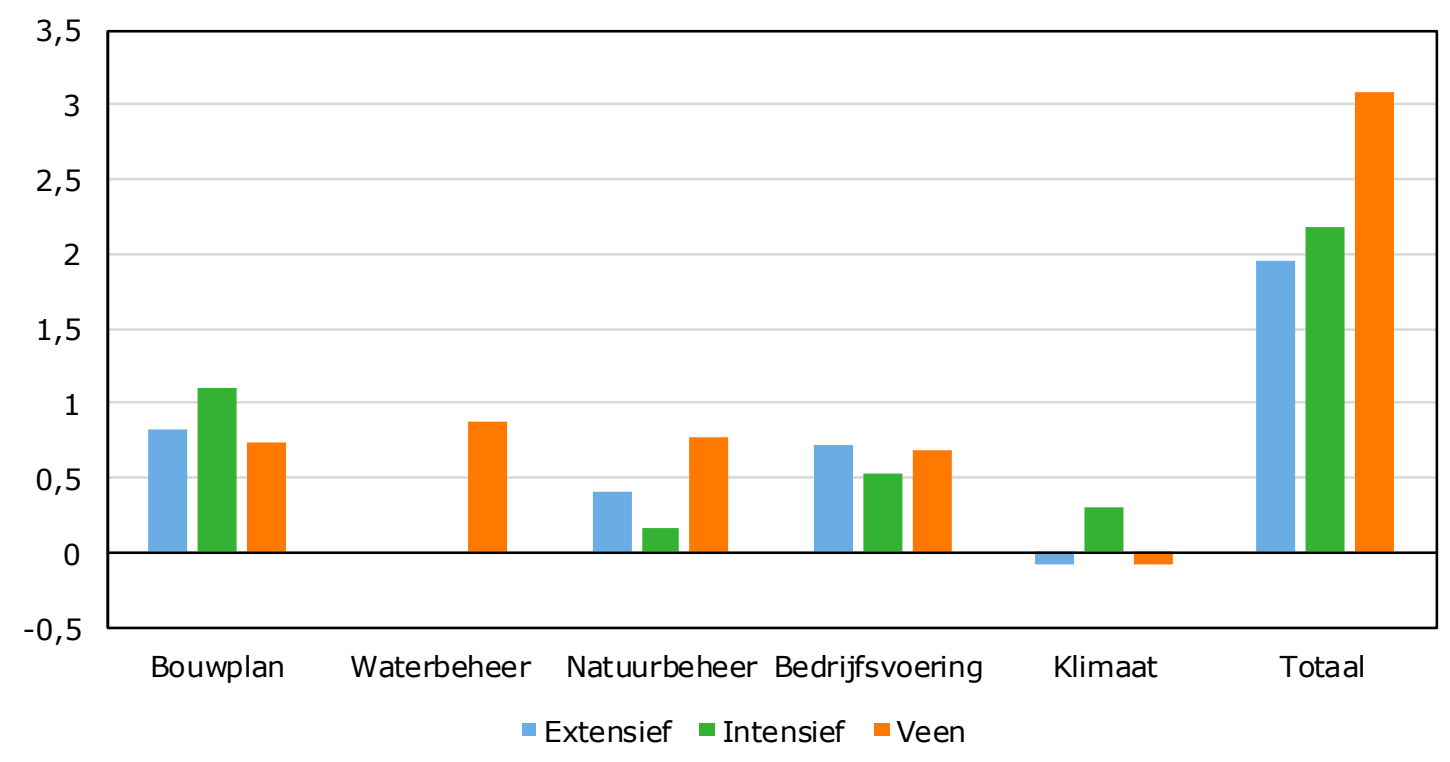

Figuur 3.1 Meerkosten op jaarbasis in $€$ per $100 \mathrm{~kg}$ melk per categorie maatregelen en in totaal voor de drie bedrijfstypen.

De meerkosten worden mede bepaald door het verschil in de uitgangssituatie. Bij het veenbedrijf is de te overbruggen afstand tussen de onderste $70 \%$ van de bedrijven (niveau A) en de bovenste $30 \%$ bedrijven (niveau B) voor de natuurbeheermaatregelen groter is dan bij de klei/zand-bedrijven. Daarnaast spelen de watermaatregelen ook een rol in de hogere meerkosten voor het veenbedrijf.

De totale kosten bedragen afgerond $€ 20.350$ voor het extensieve zand/klei-bedrijf, $€ 32.150$ voor het intensieve klei/zand-bedrijf en $€ 34.900$ voor het veenbedrijf. Op hectarebasis zijn de kosten respectievelijk $€ 302$, $€ 530$ en $€ 509$. Alle bedragen zijn op jaarbasis.

\section{Gewogen meerkosten per kg melk over bedrijfstypen heen}

In tabel 2.2 is per bedrijfstype voor zowel groep A als B weergegeven hoeveel Informatienetbedrijven er in het onderzoek zijn gebruikt en voor hoeveel melkveebedrijven in Nederland deze representatief zijn. Uitgedrukt in percentages zit van alle bedrijven met niveau A $48 \%$ in de bedrijfstypegroep extensief zand en klei, $37 \%$ in de bedrijfstypegroep intensief zand en klei en $13 \%$ in de bedrijfstypegroep veen. Wanneer deze aandelen bedrijven per bedrijfstype worden gecombineerd met de meerkosten van biodiversiteitsmaatregelen per bedrijfstype, dan resulteert dit in gewogen gemiddelde meerkosten van $€ 2,20$ per $100 \mathrm{~kg}$ melk. De gewogen kosten op bedrijfsniveau bedragen afgerond $€ 26.900$. Op hectarebasis zijn de gewogen kosten $€ 417$. Het gaat hier dus om de kosten die $70 \%$ minst presterende bedrijven moet maken op het niveau van de best presterende groep uit te komen.

\subsubsection{Kosten voor akkerbouwbedrijven}

In tabel 3.9 is de basis voor het berekenen van de kosten voor de akkerbouw weergegeven. 


\section{Tabel 3.9 Toelichting kosten per maatregel voor akkerbouwbedrijven.}

\section{Maatregel Toelichting kosten maatregel}

1 Niet-kerende grondbewerking

Bij niet-kerende grondbewerking wordt kerend ploegen (wentelploeg) vervangen door een minder diepe grondbewerking met bijvoorbeeld een schijveneg of ecoploeg (soms meerdere werkgangen); ook een diepere niet-kerende bewerking met een woelpoot kan onderdeel zijn van nietkerende grondbewerking.

In een aantal gevallen maken deze werktuigen al deel uit van de bestaande inventaris. $\mathrm{Er}$ is een jaarlijks bedrag voor advieskosten verondersteld van $€ 1000$ per bedrijf; de operationele kosten van nietkerende grondbewerking verschillen weinig van de gebruikelijke grondbewerking.

2 Aanvoer overige organische meststoffen De kosten voor aanvoer en toediening van groencompost bedragen $€ 10$ per ton.

3 Optimaal gebruik meststoffen Betere verdeling van de mest over de verschillende gewassen, advieskosten.

4 Inzet vlinderbloemigen Het betreft extra areaal van vlinderbloemigen als hoofdgewas. De financiële effecten zijn in maatregel 6 meegenomen op basis van luzerne teelt. De effecten op de meerkosten van alternatieven gewassen zoals veldbonen zijn beperkt.

5 Bloeiende akkerranden Hoofdgewas vervangen door bloemenrand. Opbrengstderving hoofdgewas naar rato van oppervlakte randen, plus kosten voor het inzaaien en onderhouden van de rand.

6 Verruiming bouwplan Bouwplan gaat naar een lager aandeel gewassen met hoge saldo's: hoogsalderende gewassen worden vervangen door rustgewassen met een lager saldo.

7 Gebruik groenbemester Volgens KWIN-AGV (2018) varieert het (negatieve) saldo van groenbemesters van $€ 150$ tot $€ 260$ per hectare. Gemiddeld is uitgegaan van $€ 200$ per ha. Een uitbreiding van $10 \%$ betreft 7,6 ha $*$ $€ 200$ is $€ 1.520$ per bedrijf, oftewel $€ 20$ per ha cultuurgrond.

8 Ruige vegetatie op overhoekjes en stimulering akker-/erfvogels

9 Gewasdiversiteit

10 Reductie onkruidbestrijdingsmiddelen

11 Reductie insecticiden
Overhoekjes worden niet beteeld. Het betreft vaak marginalere perceelsdelen; geen kosten of derving opgevoerd voor onbeteelde overhoekjes. De kosten voor de aanleg en het onderhoud van nestkasten zijn geraamd op $€ 500$ per bedrijf, conform melkveehouderij. Het effect zit in de maatregelen 'bouwplanverruiming' en 'groenbemesters'.

In de kostencalculatie is rekening gehouden met extra kosten voor mechanische onkruidbestrijding en een besparing op middelenkosten.

In plaats van standaardbespuitingen wordt pas tot bestrijding overgegaan als de insectenpopulatie het drempelniveau overschrijdt. Dit vergt een intensieve controle van de populatie en levert extra arbeidskosten op. Bovendien moet worden geïnvesteerd in kennis. Anderzijds wordt bespaard op bespuitingen. Aangenomen is dat dit wordt toegepast voor de luizenbestrijding in de consumptie- en zetmeelaardappelteelt. De netto-kosten bedragen $€ 50$ per ha aardappelen.

12 Meer winterbedekking Het effect zit in de maatregelen 'bouwplanverruiming' en 'groenbemesters'.

13 Onderploegen stro Derving van inkomsten van stro dat wordt verhakseld in plaats van verkocht: derving $€ 70$ per ha.

14 Gebruik lichtere werktuigen
De winst zal vooral geboekt moeten worden rond de oogst van aardappelen en suikerbieten. De maatregel bestaat uit het lossen van de bunkerrooier na iedere werkgang op de kopakker. De ingeschatte meerkosten zijn $€ 100$ per ha suikerbieten en $€ 50$ per ha aardappelen.

De berekening van de meerkosten leidt tot tabel 3.10. 
Tabel 3.10 Kosten op jaarbasis van maatregelen voor akkerbouwbedrijven ( $€ / h a)$.

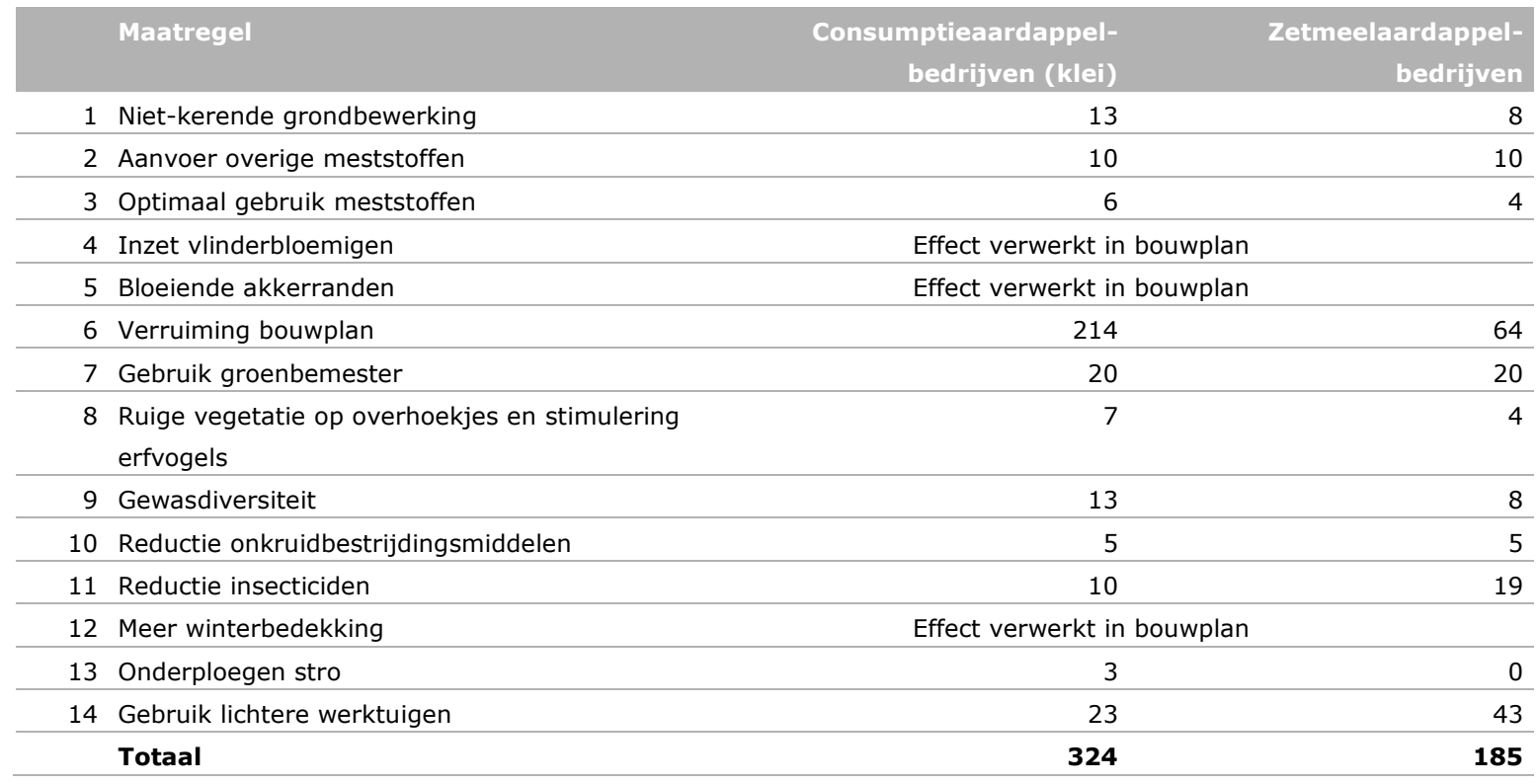

Niet-kerende grondbewerking betreft gemiddeld $5 \%$ extra van het areaal cultuurgrond. Uitgangspunt is een gelijk investeringsbedrag voor klei en zand: beide $€ 1000$ per bedrijf.

Vervanging van één hectare consumptieaardappelen door graan geeft op bedrijfsniveau al een saldonadeel van $€ 30$ per ha. Bij vervanging van meerdere hectares loopt dit nadeel navenant op. Voor een bloemenrand op rooigewassen is het verschil groter dan bij de teelt van granen omdat de rand niets oplevert. Bij de maatregelen valt met name één kostenpost op. De aangehouden verruiming van het bouwplan leidt tot een verhoging van de kosten van $€ 214$ respectievelijk $€ 64$ per hectare, wat een logisch gevolg is van de afname van het aandeel hoogsalderende gewassen.

De geraamde meerkosten voor akkerbouwbedrijven met het bouwplan consumptieaardappelen of zetmeelaardappelen zijn respectievelijk $€ 324$ en $€ 185$ per hectare. Op bedrijfsniveau zijn de meerkosten respectievelijk $€ 24.624$ en $€ 22.755$. 


\section{Conclusies, discussie en aanbevelingen}

\subsection{Conclusies}

Om tot een integraal betere score op meerdere indicatoren voor biodiversiteit (KPI's) te komen, is voor zowel de melkveehouderij als de akkerbouw een breed pakket aan maatregelen nodig. Het is belangrijk om het gehele maatregelenpakket dat op verschillende onderdelen van de bedrijfsvoering aangrijpt in ogenschouw te nemen. De totale set aan maatregelen zorgt voor een verbetering op alle biodiversiteits-KPI's en heeft effect op de kostprijs.

De kosten om integraal beter te scoren op indicatoren uit de biodiversiteitsmonitor zijn voor drie bedrijfstypen berekend. De meerkosten komen voor intensieve melkveebedrijven, extensieve melkveebedrijven en bedrijven op veen respectievelijk $€ 1,95, € 2,18$ en $€ 3.08$ per honderd $\mathrm{kg}$ melk. Gewogen over de drie bedrijfstypen in de melkveehouderij zijn de meerkosten $€ 2,21$ per honderd $\mathrm{kg}$ melk en $€ 417$ per hectare. De geraamde meerkosten voor akkerbouwbedrijven op klei met een bouwplan met consumptieaardappelen of op zand met een bouwplan met zetmeelaardappelen zijn respectievelijk $€ 324$ en $€ 185$ per hectare. Voor alle bedrijfstypen geldt dat het gaat om meerkosten voor de $70 \%$ van de bedrijven die het niveau van de $30 \%$ beste bedrijven willen gaan behalen. Ter vergelijking: over de afgelopen 5 jaar was het gemiddelde inkomen uit bedrijf op melkveebedrijven 1000 euro/ha en op akkerbouwbedrijven 800 euro/ha (Bron: Bedrijven Informatie Net van Wageningen Economic Research). Gerelateerd aan het inkomen vormen de meerkosten een substantieel bedrag.

Voor melkveebedrijven hebben de maatregelen betrekking op het bouwplan (een groter aandeel gras als vervanger van mais en een groter aandeel blijvend grasland), directe natuurmaatregelen, aanpassingen in de bedrijfsvoering (meer beweiding, minder kunstmestbemesting, optimalisatie bemesting, optimalisatie voeding, levensduurverlenging, werken met lichtere machines) en maatregelen die gericht zijn op het klimaat (zonnepanelen en gebruik van krachtvoer met een lagere footprint). De inzet en impact op de bedrijfsvoering van maatregelen verschilt tussen de verschillende bedrijfstypen omdat de uitgangssituatie anders is. Voor de bedrijven binnen een bedrijfstype zal de inzet van maatregelen en de score op KPI's verschillen. In dit onderzoek is gekeken naar het gemiddelde bedrijf.

Voor akkerbouwbedrijven hebben de maatregelen met name betrekking op de bodem. Het meer toepassen van niet-kerende grondbewerking, het aanvoeren of vasthouden van extra organische stof en het gebruik van lichtere machines in combinatie met een bouwplan met meer rustgewassen zal naar verwachting tot een betere bodemkwaliteit leiden. Daarnaast wordt de bemesting geoptimaliseerd en wordt het gebruik van gewasbeschermingsmiddelen gereduceerd. De natuurbeheermaatregelen worden ingevuld door bloeiende akkerranden en ruige vegetatie in overhoekjes. Ook voor de akkerbouw is de intensiteit van de maatregelen afhankelijk van het bedrijfstype (bouwplan) en de grondsoort.

\subsection{Discussie}

In dit onderzoek is een integrale score op de KPI's uit de biodiversiteitsmonitor op basis van praktijkbedrijven als basis gebruikt, waarbij alle KPI's even zwaar mee tellen. Voor een tweetal KPI's (areaal agrarisch natuurbeheer en kruidenrijk grasland) zijn proxy's gebruikt omdat de KPI zelf niet in de beschikbare boekhoudingen is opgenomen. In hoeverre de integrale score op KPI's ook daadwerkelijk een relatie heeft met de biodiversiteit viel buiten de scope van dit onderzoek, maar is uiteraard zeer relevant voor het onderwerp. 
De integraliteit is in dit onderzoek ingevuld door bedrijven in te delen op basis van een gemiddelde score op alle KPI's. Dit betekent dat er ruimte is voor compensatie. Een bedrijf dat laag scoort op één indicator kan dit in deze systematiek compenseren door een hoge score op andere indicatoren. In de bijeenkomsten met de experts en de begeleidingscommissie bleek dat hier verschillend tegenaan wordt gekeken. Er lijkt wel een consensus te zijn dat op individuele indicatoren aan bepaalde minimumeisen zou moeten worden voldaan, maar welk niveau dat dan moet zijn, is nog niet duidelijk. Aan de andere kant lijkt er ook behoefte te zijn aan een bepaald niveau van compensatiemogelijkheden omdat daarmee de diversiteit in de praktijk beter kan worden benut en de ondernemer ook zijn sterke punten beter kan benutten.

De ontwikkelaars van de biodiversiteitsmonitor zien een toepassing van de monitor voor zich die gebaseerd is op 'optimale ecologische waarden' en 'drempelwaarden' voor de KPI's. Optimale ecologische waarden voor een KPI geven vanuit biodiversiteitsoogpunt de meest ideale situatie weer. Drempelwaarden geven een minimale waarde van een KPI waarbij er een positief effect op de biodiversiteit is te verwachten. Idealiter geeft het voldoen aan de drempelwaarden voor alle KPI's een basiskwaliteit voor een biodiverse melkveehouderij weer.

Een alternatieve aanpak voor dit onderzoek om meerkosten uit te rekenen zou zijn om voor (individuele) bedrijven vast te stellen welke maatregelen genomen zouden moeten worden om aan alle drempelwaarden te voldoen en dat te aggregeren tot totale meerkosten. Een soortgelijke berekening zou ook voor de optimale ecologische waarden kunnen worden gemaakt. Deze methode is hier niet toegepast omdat dit bewerkelijk is voor meer dan driehonderd bedrijven met locatiespecifieke en bedrijfsspecifieke factoren binnen de context van dit onderzoek. Dit had overigens ook nog niet gekund omdat de betreffende waarden nog niet zijn vastgesteld. Een onderzoek naar deze waarden loopt op dit moment. Een ander punt rond de biodiversiteitsmonitor is dat de combinatie van indicatoren mede zo gekozen is om afwenteling naar andere duurzaamheidsaspecten te vermijden. Een sterke sturing op bijvoorbeeld verschraald kruidenrijk grasland zou ertoe kunnen leiden dat er op het bedrijf minder melk wordt geproduceerd of dat de lagere voerproductie op dit grasland wordt gecompenseerd door hogere bemesting op de andere percelen, wat dan weer tot hogere bodemoverschotten zou kunnen leiden. In het geval van een lagere melkproductie op het bedrijf kan er afwenteling optreden als deze melk vervolgens elders wordt geproduceerd.

De maatregelen in het onderzoek zijn zo gekozen dat ze passen binnen de huidige bedrijfsstructuur met een tijdshorizon van vijf jaar. Op lange termijn kan een ondernemer zijn bedrijf meer aanpassen dan op de korte termijn. Voor de melkveebedrijven is bij voorbeeld (nog) geen extensiveringsmaatregel toegepast en voor de akkerbouw is er nog geen strokenteelt. Beide voorbeelden kwamen in de expertworkshop aan de orde, maar kregen voor de korte termijn nog geen hoge prioriteit. Andere maatregelen overstijgen het individuele bedrijf, zoals de samenwerking met andere ondernemers. Voor extensivering is meer grond nodig. Dit raakt andere sectoren en kan van invloed zijn op de grondprijzen. Een andere manier van extensiveren is minder melk produceren. Dat heeft gevolgen voor de vaste kosten en kan leiden tot afwenteling, waarbij de melk elders wordt geproduceerd. Overigens is het wel van belang om ook de effecten van deze meer structurele maatregelen beter in kaart te brengen.

In het onderzoek is een beperkt aantal bedrijfstypen onderscheiden. De meerkosten zijn berekend per bedrijfstype voor de gemiddelde situatie van de groep bedrijven. In de praktijk is de diversiteit veel groter, waarbij in het uiterste geval elk bedrijf afzonderlijk moet worden bekeken. Dit betekent dat de impact qua kosten van de gekozen maatregelenpakketten voor individuele bedrijven sterk kan variëren. Dit geldt bijvoorbeeld voor melkveebedrijven die in de huidige situatie grond ruilen met akkerbouwers voor bijvoorbeeld de aardappel- of de bollenteelt. Dit systeem is gebaseerd op tijdelijk grasland en gaat niet samen met blijvend grasland. In ander onderzoek is hier specifiek naar gekeken (De Wolf et al., 2018). Voor een Noord-Hollandse casus was het voordeel voor het melkveebedrijf van deze vorm van samenwerking zo'n $€ 20.000$. Voor een bedrijf dat 1 miljoen $\mathrm{kg}$ melk produceert, is dat $€ 2$ per $100 \mathrm{~kg}$ melk. Voor de akkerbouwer was het berekende voordeel nog aanzienlijk hoger, met name doordat de akkerbouwer relatief meer hoogsalderende gewassen kon telen op schone grond bij de melkveehouder. Een ander voorbeeld is weidegang. In alle drie de bedrijfstypen voor melkvee wordt meer beweid dan in de uitgangssituatie. Het is niet voor alle bedrijven mogelijk om te beweiden. Naar schatting kan circa $7 \%$ van de bedrijven geen weidegang toepassen vanwege een te kleine huiskavel (van den Pol, 2015). 
In het onderzoek is niet exact bepaald of het B-niveau voor elke afzonderlijke KPI wordt gehaald. Voor melkvee geldt dat voor blijvend grasland mede op basis van input van de reviewers de maatregel minder ver is doorgevoerd voor de klei/zand-bedrijven. Voor de overige KPI's is kwalitatief beoordeeld door de experts en later door de reviewers dat niveau B wordt gehaald met het maatregelenpakket. Voor de akkerbouwbedrijfstypen wordt niveau B voor het gebruik van gewasbeschermingsmiddelen waarschijnlijk net niet gehaald. Voor de overige KPI's is de inschatting dat niveau B wordt gehaald, voor organische stof ruimschoots.

Het onderzoek richt zich op bedrijfstypen en op maatregelen die op bedrijfsniveau kunnen worden genomen. Zoals aangegeven zijn in de praktijk specifieke regionale/lokale omstandigheden erg bepalend voor de exacte maatregelen die moeten worden genomen op een individueel bedrijf. Een ander belangrijk aspect is dat voor het verbeteren van biodiversiteit de samenhang van maatregelen op gebiedsniveau vaak cruciaal is. De samenhang van de maatregelen op gebiedsniveau en de eventueel daaruit volgende extra kosten zijn in dit onderzoek niet meegenomen. In het onderzoek is niet gekeken naar effecten op de kostprijs van maatregelen die het primaire bedrijf overschrijden (bijvoorbeeld het regionale effect van verkleining van het aandeel rooivruchten in het bouwplan) of naar andere ontwikkelingen in de (directe) omgeving van de bedrijven, zoals de keten of bedrijven die stoppen.

Het onderzoek richtte zich op het berekenen van de meerkosten van maatregelenpakketten om de biodiversiteit te verbeteren. Er is geen aandacht besteed aan de manier waarop de daadwerkelijke implementatie van deze maatregelen gestimuleerd zouden kunnen worden. Dit is een belangrijk aspect omdat het om een breed pakket aan maatregelen gaat die op diverse terreinen om aanpassingen in het management vragen. Daarbij is het ook belangrijk om rekening te houden met het feit dat de bedrijfsopzet en bedrijfsvoering ook mede bepaald worden door regelgeving of randvoorwaarden voor premies.

\subsection{Aanbevelingen}

De benadering met een beperkt aantal bedrijfstypen leidt ertoe dat er geen rekening wordt gehouden met de grote diversiteit in de praktijk. Het is aan te bevelen om, als de drempelwaarden concreet bekend zijn, specifiek te kijken naar welke maatregelen door grotere aantallen verschillende bedrijven en bedrijfstypen zouden kunnen of moeten worden genomen om aan de waarden te kunnen voldoen en wat dit betekent voor de KPI's en voor de kosten. Op deze manier kunnen kansen en mogelijke knelpunten voor groepen bedrijven worden gesignaleerd. Met behulp van micro-economische modellen kan het onderzoek meer recht doen aan de diversiteit in de praktijk en kan mogelijk ook beter geoptimaliseerd worden.

De focus in het onderzoek lag op melkvee- en akkerbouwbedrijven afzonderlijk. De akkerbouwbedrijven die veel grond ruilen met andere bedrijven zijn bijvoorbeeld niet meegenomen in het onderzoek. Ook de interactie tussen akkerbouw en melkveehouderij kwam niet aan bod. Rond kringlooplandbouw is veel aandacht voor de samenwerking tussen akkerbouw en melkveehouderij. Het is aan te bevelen om deze samenwerking afzonderlijk te bekijken: wat kan dit opleveren voor biodiversiteit en wat betekent dit voor de kosten?

Dit onderzoek richt zich op maatregelen die door een brede groep akkerbouwers en melkveehouders genomen kunnen worden om hoger te scoren op de KPI's. Dit is niet het droombeeld voor het Deltaplan Biodiversiteit. Het is aan te bevelen om dit droombeeld te concretiseren met KPI's. Dit vraagt een andere onderzoeksaanpak. Het niveau zal nader gedefinieerd moeten worden, want dat zal niet zonder meer uit praktijkgegevens van grote groepen bedrijven kunnen worden afgeleid. De praktijkgegevens kunnen wel een referentie bieden voor de transitie die zal moeten plaatsvinden. Het is te verwachten dat duidelijk verdergaande maatregelen genomen zullen moeten worden om aan het droombeeld te kunnen voldoen. De implementatie van deze verdergaande maatregelen zal meer tijd kosten en zal gepaard gaan met grotere investeringen, inclusief bijvoorbeeld aanpassingen in stalsystemen en aanpassingen in de structuur van bedrijven. 
Het definiëren van maatregelen en het doorrekenen van kosten is één stap. Het ontwikkelen van een plan om tot implementatie van de maatregelen in de praktijk te komen, is duidelijk een andere stap. Het is aan te bevelen om hier een gedegen plan voor te ontwikkelen dat rekening houdt met de volle breedte van het maatregelenpakket, de gevolgen voor de ondernemer en de rol van de omgeving van de ondernemer, waaronder de adviseurs.

Op dit moment worden nog niet alle indicatoren uit de biodiversiteitsmonitor verzameld in het Bedrijveninformatienet. Het verdient aanbeveling om op korte termijn te starten met het vastleggen van deze indicatoren. Overigens is voor sommige indicatoren (bijvoorbeeld kruidenrijk grasland) op dit moment ook nog geen eenduidige definitie voorhanden. 


\section{Literatuur en websites}

Booij, A., 2014, Minder jongvee, meer melkvee. Ruimte in ammoniak, fosfaat en vergunning creëren door minder jongvee op te fokken. Veeteelt, November 2, pp 22-23

Daatselaar, C., J. den Hartogh, A. Beldman en M. Chen, 2018. Identification of best performing dairy farms in the Netherlands, https://edepot.wur. nl/472847

Deltaplan Agrarisch Waterbeheer, Infiltratie via onderwaterdrainage. https://agrarischwaterbeheer.nl/system/files/documenten/boek/infiltratie_via_onderwaterdrainage .pdf

Doornewaard, G.J., J.W. Reijs, A.C.G. Beldman, J.H. Jager en M.W. Hoogeveen, 2018. Sectorrapportage Duurzame Zuivelketen; Prestaties 2017 in perspectief. Wageningen, Wageningen Economic Research, Rapport 2018-094. 226 blz.; 24 fig.; 23 tab.; 95 ref.

Eekeren, N. van, 2016, Optimaal landgebruik voor bodemkwaliteit. V-focus December 2016, pp 34-35

Geerts, Rob en Koos Verloop, Het belang van kruiden en vlinderbloemigen in grasland. NVWV studiedag 17-4-2007, Landhorst www.nvwv.nl/sites/default/files/files/151___rob_geerts.pdf

Grondig, Graslandvernieuwing, Argumenten, feiten en cijfers. Grondig maart 2011, pp 40-41. http://edepot.wur.nl/167623

Ge, L., R.W. van der Meer, H.B. van der Veen en H.C.J. Vrolijk, 2018. Sample of Dutch FADN 2015: Design principles and quality of the 192 | Wageningen Economic Research Rapport 2018-094 sample of agricultural and horticultural holdings. Report 2018-011. Wageningen. Wageningen Economic Research.

Kennisprogramma bodemdaling, Factsheet onderwater- en drukdrainage, Veel gestelde vragen over onderwaterdrainage en drukdrainage, 2018, http://www.kennisprogrammabodemdaling. nl/home/wp-content/uploads/2019/05/FactsheetOnderwater-drukdrainage-2018.pdf

KWIN, 2018, KWIN Kwantitatieve Informatie Veehouderij 2018-2019. Handboek 36. Wageningen: Wageningen UR Livestock Research

KWIN-AGV, 2018, Kwantitatieve Informatie Akkerbouw en Vollegrondsgroenteteelt, Wageningen

Laarhoven, Guus, Jeen Nijboer, Natasja Oerlemands, Richard Piechoki, Jacomijn Pluimers, 2018. Biodiversiteitsmonitor melkveehouderij

Lieftink, H.J., 2019, persoonlijke mededeling

Natuur en Milieufederatie Groningen, IMSA, Valuta voor veen. Een haalbaarheidsstudie naar het vernatten van veengebieden en het verhandelen van hierdoor behaalde emissiereducties. Groningen, December 2014.

Van den Pol-van Dasselaar, A., P.W. Blokland, T.J.A. Gies, M.H.A. de Haan, G. Holshof, H.S.D. Naeff, A.P. Philipsen, 2015. Beweidbare oppervlakte en weidegang op melkveebedrijven in Nederland. Wageningen, Wageningen UR (University \& Research) Livestock Research, Livestock Research Rapport 917.

Reijs, J.W. C.H.G. Daatselaar, J.F.M. Helming, J. Jager and A.C.G. Beldman, 2013, Grazing dairy cows in North-West Europe; Economic farm performance and future developments with emphasis on the Dutch situation, LEI Report 2013-001

Van Schooten, H., H. Dirksen, Meten van voerefficiëntie voor betere benutting van eigen ruwvoer. Januari 2013, Wageningen Livestock Research. https://edepot.wur.nl/425784

Šebek, L.B., Mosquera, J., Bannink, A. 2016. Rekenregels voor de enterische methaanemissie op het melkveebedrijf en reductie van de methaanemissie via mest-handling; het handelingsperspectief van het voerspoor inzichtelijk maken met de Kringloopwijzer. Lelystad, Wageningen UR (University \& Research) Livestock Research, Livestock Research Rapport 976.

Schröder, J.J., L.B. Sebek, J. Oenema, J.G. Conijn \& J. de Boer, 2018, Rekenregels van de kringloopWijzer 2017; Achtergronden van BEX, BEA, BEN, BEP en BEC: actualisatie van de 2016versie. Wageningen Research, Rapport WPR-790

Smit, B. en J. Jager. 2018. Schets van de akkerbouw in Nederland: Structuur-, landschaps- en milieukenmerken die een relatie hebben tot biodiversiteit, notitie Wageningen University \& Research, https://edepot.wur.nl/463816 
Spruijt, J., A. Terbijhe, 2016 Perspectief zonnestroom in de agrarische sector, Accres, Wageningen UR, rapport PPO-nummer 690. https://edepot.wur.nl/377525

Wit, J. de, W. Schippers, R.H.E.M. Geerts, J.P. Wagenaar en N. van Eekeren Advies: inzaai- en beheer kruidenrijk grasland voor weidevogels, Noord-Holland. Bunnik/Wageningen 16 augustus 2017, https://www.collectiefnhz.nl/assets/uploads/files/rapporten/Advies\%20kruidenrijk\%20mengsel\%2 ONH.pdf

Wemmenhove, Harm, persoonlijke mededeling 2019

Wolf, P. de, W. van Dijk en K. Klompe, 2018, Samenwerking tussen agrarische sectoren in NoordHolland: analyse en aandachtpunten op bedrijfs- en regioniveau. Nederland: Vruchtbare Kringloop Noord-Holland. 47 p. (WUR publicatie; no. 768)

Zijlstra, J., P.W. Blokland, N. van Eekeren, G. Migchels, N. Polman en M. Bestman. 2016 Monitoring van functionele agrobiodiversiteit in de melkveehouderij: ontwikkeling van KPI's, Wageningen Livestock Research, Rapport 984.

Zijlstra, J., M. Boer, J. Buiting, K. Colombijn-Van der Wende en E.-A. Andringa, 2013, Routekaart levensduur, Wageningen Livestock Research, Rapport 668.

\section{Websites:}

CBS, Statline. https://opendata.cbs.nl/statline/\#/CBS/nl/dataset/80785ned/table?ts=1567501694946

Bij12, Tarieven Natuur en Landschapsbeheer, https://www.bij12.nl/onderwerpen/natuur-enlandschap/subsidiestelsel-natuur-en-landschap/subsidiestelsel-natuur-en-landschap/tarieven/ Website Deltaplan

https://www.samenvoorbiodiversiteit. nl/het-droombeeld-voor-2030-een-florerende-delta-voormens-en-natuur/ 


\section{Bijlage 1 Typen melkveebedrijven kenmerken bedrijf en bedrijfsvoering}

\begin{tabular}{|c|c|c|c|c|c|c|}
\hline & \multicolumn{3}{|c|}{ Klei en zand } & \multicolumn{3}{|c|}{ Veen } \\
\hline & Extensief & & Intensief & & & \\
\hline & A & B & A & B & A & B \\
\hline Koeien (aantal) & 115 & 100 & 158 & 158 & 128 & 92 \\
\hline Veebezetting (gve/ha) & 2,2 & 2,0 & 3,3 & 2,7 & 2,5 & 2,2 \\
\hline Jongvee/tien melkkoeien & 6,2 & 6,0 & 6,1 & 5,7 & 6,1 & 5,6 \\
\hline Melkproductie bedrijf $(\mathrm{kg})$ & 1.043 .225 & 844.733 & 1.472 .234 & 1.392 .637 & 1.134 .649 & 769.290 \\
\hline Intensiteit (kg melk/ha) & 15.286 & 13.277 & 24.266 & 18.503 & 16.415 & 13.854 \\
\hline Melkproductie per koe (kg) & 8.929 & 8.249 & 9.187 & 8.487 & 8.655 & 7.810 \\
\hline Cultuurgrond (ha) & 67,4 & 63,2 & 60,7 & 71,8 & 68,6 & 50,8 \\
\hline Gras (ha) & 55,4 & 52,6 & 46,9 & 61,9 & 62,1 & 48,7 \\
\hline Aandeel gras (\%) & 83 & 85 & 79 & 88 & 91 & 98 \\
\hline Mais (ha) & 9,9 & 9,4 & 12,0 & 9,9 & 6,5 & 2,0 \\
\hline Overig (ha) & 2,2 & 1,2 & 1,7 & 0,0 & 0,0 & 0,0 \\
\hline Weidedagen/jaar & 148 & 150 & 81 & 124 & 121 & 186 \\
\hline Weide-uren/dag & 8,1 & 8,7 & 3,9 & 6,1 & 7,5 & 13,2 \\
\hline Kunstmestgift (kg N/ha) & 139 & 119 & 138 & 152 & 124 & 116 \\
\hline Dierlijke mestgift (kg N/ha) & 198,9 & 190,6 & 225,7 & 217,8 & 213,5 & 163,9 \\
\hline Weidemest (kg N/ha) & 47,3 & 42,6 & 36,2 & 38,1 & 49,5 & 72,8 \\
\hline Graslandopbrengst (kg ds) & 9.333 & 9.769 & 10.917 & 12.035 & 10.210 & 9.425 \\
\hline Graslandopbrengst (kg kVEM) & 8.926 & 9.422 & 10.689 & 11.721 & 9.806 & 9.043 \\
\hline Graslandopbrengst (kg N) & 282 & 289 & 337 & 376 & 323 & 294 \\
\hline Graslandopbrengst $\left(\mathrm{kg} \mathrm{P}_{2} \mathrm{O}_{5}\right)$ & 78 & 82 & 95 & 99 & 80 & 74 \\
\hline Maislandopbrengst (kg kVEM) & 18.460 & 19.080 & 20.099 & 20.162 & 18.740 & 14.092 \\
\hline Maislandopbrengst ( $\mathrm{kg} \mathrm{ds}$ ) & 17.965 & 18.627 & 19.643 & 19.506 & 18.140 & 13.655 \\
\hline Maislandopbrengst (kg N) & 201 & 206 & 218 & 224 & 204 & 136 \\
\hline Maislandopbrengst $\left(\mathrm{kg} \mathrm{P}_{2} \mathrm{O}_{5}\right)$ & 73 & 73 & 82 & 78 & 77 & 53 \\
\hline Eiwitgehalte rantsoen ( $\mathrm{g}$ ruw eiwit/kg ds) & 170 & 166 & 165 & 169 & 180 & 183 \\
\hline Eiwitgehalte rantsoen ( $\mathrm{g}$ ruw eiwit/kg product) & 189 & 176 & 213 & 183 & 172 & 161 \\
\hline Krachtvoergift (kg/100 kg melk) & 28,5 & 24,8 & 27,2 & 28,0 & 29,3 & 30,4 \\
\hline Voerefficiëntie (kg melk/kg ds voeropname) & 1,06 & 1,01 & 1,09 & 1,05 & 1,05 & 1,08 \\
\hline Voerefficiëntie (kg meetmelk/kg ds voeropname) & 1,12 & 1,08 & 1,16 & 1,11 & 1,09 & 1,01 \\
\hline Aandeel vers gras rantsoen (\%) & 14 & 16 & 8 & 12 & 14 & 23 \\
\hline Aandeel geconserveerd gras rantsoen (\%) & 34 & 39 & 28 & 38 & 40 & 39 \\
\hline Aandeel snijmais rantsoen (\%) & 20 & 18 & 29 & 19 & 12 & 5 \\
\hline Aandeel krachtvoer/melkprod. rantsoen (\%) & 27 & 23 & 27 & 26 & 28 & 30 \\
\hline Aandeel overig ruwvoer/bijprod. rantsoen (\%) & 4 & 5 & 8 & 5 & 7 & 4 \\
\hline Ureumgetal & 21,8 & 22,4 & 22,1 & 22,2 & 23,7 & 22,6 \\
\hline
\end{tabular}




\section{Bijlage 2 Literatuurbronnen longlist biodiversiteitsmaatregelen}

- Bouma, J., M. Koetse \& N. Polman (2019) Financieringsbehoefte natuurinclusieve landbouw. Rapportage eerste fase: beschrijvende analyse vragenlijst, Den Haag: PBL

- Derks, T., B. Aasman, A. Evers en J. de Wit (2012) Resultaten berekeningen bedrijfsmaatregelen Melkveehouderij en Akkerbouw. DL, Louis Bolk en WLR

- Dijk, W. van, Spruijt, J., Runia, W. T., \& van Geel, W. C. A. (2012) Verruiming vruchtwisseling in relatie tot mineralenbenutting, bodemkwaliteit en bedrijfseconomie op akkerbouwbedrijven. Praktijkonderzoek Plant \& Omgeving, Business Unit AGV.

- Erisman, J. W., van Eekeren, N. J. M., Cuijpers, W. J., \& de Wit, J. (2014) Biodiversiteit in de melkveehouderij: investeren in veerkracht en reduceren van risico's. Louis Bolk Instituut.

- Erisman, J. W., van Eekeren, N., van Doorn, A., Geertsema, W., \& Polman, N. (2017) Maatregelen Natuurinclusieve landbouw (No. 2821). Wageningen Environmental Research.

- Laarhoven, G. van, J. Nijboer N. Oerlemans, R. Piechocki, J. Pluimers (2018) Biodiversiteitsmonitor Melkveehouderij. WNR, Friesland Campina en Rabobank

- Rougoor, C. en F. van der Schans (2017) Meerkosten duurzame melkveehouderij, CLM

- Schootsman, W, W. Rozendaal, M. Schultinga, D. Nigten (2019) Maatregelen natuurinclusieve landbouw Oost-Groningen. Aequator/ANOG

- Sukkel, W. (en anderen) (2019) Proeftuin Agroecologie en Technologie

- Visser, A., Leendertse, P. C., Den Boer, D. J., \& Termorshuizen, A. J. (2008) Gereedschapskist voor biodiversiteit en landbouw. Beschrijving en aanpak maatregelen. Culemborg.

- Zanen, M. (2017). Ontwikkeling van KPI's voor landschappelijke diversiteit en specifieke soorten. Onderdeel van de Biodiversiteitsmonitor Melkveehouderij. Louis Bolk instituut.

- Zijlstra, J., J.J. Poelarends, G. Migchels en F.A.N. van Alebeek. Routekaart Biodiversiteit. Wageningen UR (University \& Research) Livestock Research. Rapport 820 


\section{Bijlage 3 Deelnemers expertworkshop}

\section{Melkveehouderij}

Wilco Brouwer de Koning (LTO)

Bram Derikx (Horizon Advies)

Anne van Doorn (Wageningen Environmental Research, deel van de sessie)

Gerben Doornewaard (Wageningen Economic Research)

Guus van Laarhoven (FrieslandCampina)

Gera van Os (Aeres)

Willem Rienks (ROM3D)

Frits van der Schans (CLM)

Inge van Schie (LTO)

Jan de Wit (Louis Bolk Instituut)

Jelle Zijlstra (Wageningen Livestock Research)

\section{Akkerbouw}

Anne van doorn (Wageningen Environmental Research, deel van de sessie) Willemien Geertsema (BoerenNatuur)

Bas Janssens (Wageningen University \& Research)

Raymond Klaassen (Rijksuniversiteit Groningen)

Wijnand Sukkel (Wageningen Plant Research)

Jaap van Wenum (LTO/BO Akkerbouw)

Cees Witkamp (Vogelbescherming)

Marleen Zanen (LBI) 


\section{Bijlage 4 Resultaat expertworkshop: prioriteiten van maatregelen}

Voor elk bedrijfstype is de top drie van maatregelen weergegeven per categorie maatregelen. Daarnaast zijn de maatregelen met een score van 3,0 of hoger weergegeven. Voor akkerbouw is per categorie de top vier weergegeven.

Tabel B4.1 Resultaat expertworkshop voor bedrijfstype melkvee intensief.

\begin{tabular}{|c|c|c|c|c|}
\hline & Type maatregel & & Meest gekozen maatregel & $\begin{array}{l}\text { Score } \\
\text { maatregel }\end{array}$ \\
\hline \multirow[t]{3}{*}{1} & Graslandbeheer & 1 & Graslandmengsels, kruidenrijk met andere soorten & 4,2 \\
\hline & & 3 & Maaibeheer, beweiding & 3,9 \\
\hline & & 4 & Graslandmengsels, doorzaai klaver & 3,7 \\
\hline \multirow{2}{*}{2} & \multirow{2}{*}{ Bouwplan en gewaskeuze } & 2 & Vergroten aandeel blijvend grasland in bouwplan & 4,3 \\
\hline & & 3 & Alternatieve voedergewassen telen (bijv. grasklaver, soja, bonen) & 3,5 \\
\hline \multirow[t]{2}{*}{3} & Bemesting & 1 & Precisiebemesting & 5,8 \\
\hline & & 2 & Verminderen gebruik kunstmest & 5,5 \\
\hline \multirow{2}{*}{4} & & 3 & Organischestofbalans: compost & 3,8 \\
\hline & & 4 & Machines: lichte machines en lage bandenspanning & 3,1 \\
\hline \multirow[t]{3}{*}{5} & Landschapselementen & 1 & Landschapselementen: lijn & 4,3 \\
\hline & & 2 & Randenbeheer, akkerranden & 3,6 \\
\hline & & 3 & Natuurlijk slootkantbeheer (incl. afrasteren) & 3,3 \\
\hline \multirow[t]{3}{*}{6} & \multirow{3}{*}{$\begin{array}{l}\text { Locatiegebonden en } \\
\text { samenwerking }\end{array}$} & 1 & Samenwerking, veevoer van akkerbouwer & 6,9 \\
\hline & & 2 & Samewerking, rotatie akkerbouw (grasland) & 4,6 \\
\hline & & 3 & Agro-forestry & 1,3 \\
\hline 7 & $\begin{array}{l}\text { Stallen, mestopslag en } \\
\text { bewerking }\end{array}$ & 1 & Mest, scheiding & 6,9 \\
\hline \multirow[t]{3}{*}{9} & Specifieke soorten & 1 & Erfvogels stimuleren (o.a. zwaluwen in of bij de stal laten nestelen) & 4,4 \\
\hline & & 2 & Andere overeenkomsten agrarisch natuurbeheer (specificeer) & 3,2 \\
\hline & & 3 & Weidevogelbeheer, mozaïekbeheer & 2,7 \\
\hline \multirow[t]{3}{*}{10} & Diermanagement & 1 & Veestapel, vervangingspercentage verlagen, levensduur verhogen & 5,0 \\
\hline & & 2 & Fokkerij, weerstand koe verhogen & 3,5 \\
\hline & & 3 & Andere rassen, dubbeldoelkoeien & 3,4 \\
\hline
\end{tabular}


Tabel B4.2 Resultaat expertworkshop voor bedrijfstype melkvee veen.

\begin{tabular}{|c|c|c|c|c|}
\hline & Type maatregel & & Meest gekozen maatregel & $\begin{array}{l}\text { Score } \\
\text { maatregel }\end{array}$ \\
\hline \multirow[t]{2}{*}{1} & Graslandbeheer & 1 & Maaibeheer, beweiding & 4,9 \\
\hline & & 3 & Graslandmengsels, kruidenrijk met andere soorten & 2,8 \\
\hline \multirow[t]{2}{*}{2} & \multirow[t]{2}{*}{ Bouwplan en gewaskeuze } & 1 & Minder mais en meer gras & 7,9 \\
\hline & & 3 & Alternatieve voedergewassen telen (bijv. grasklaver, soja, bonen) & 1,1 \\
\hline \multirow[t]{3}{*}{3} & Bemesting & 1 & Verminderen gebruik kunstmest & 6,6 \\
\hline & & 2 & Optimalisatie dikke/dunne mest & 5,2 \\
\hline & & 3 & Precisiebemesting & 5,2 \\
\hline \multirow[t]{3}{*}{5} & Landschapselementen & 1 & Natuurlijk slootkantbeheer (incl. afrasteren) & 6,5 \\
\hline & & 2 & Landschapselementen: lijn & 3,1 \\
\hline & & 3 & Plasdras aanleggen & 2,4 \\
\hline \multirow[t]{3}{*}{6} & \multirow{3}{*}{$\begin{array}{l}\text { Locatiegebonden en } \\
\text { samenwerking }\end{array}$} & 1 & Veen, hoger waterpeil & 6,4 \\
\hline & & 2 & Veen, drainage & 5,3 \\
\hline & & 3 & Samenwerking, veevoer van akkerbouwer & 2,5 \\
\hline \multirow[t]{3}{*}{7} & \multirow{3}{*}{$\begin{array}{l}\text { Stallen, mestopslag en } \\
\text { bewerking }\end{array}$} & 1 & Mest, scheiding & 5,7 \\
\hline & & 2 & Stal en opslag, emissiearm (RAV-lijst) & 4,2 \\
\hline & & 3 & Mest toedienen, emissiearm (grasland en bouwland) & 3,3 \\
\hline 9 & & 3 & Weidevogelbeheer, mozaïekbeheer & 2,6 \\
\hline \multirow[t]{3}{*}{10} & Diermanagement & 1 & Veestapel, vervangingspercentage verlagen, levensduur verhogen & 5,5 \\
\hline & & 2 & Andere rassen, in combinatie met natte landbouw (veen) & 4,2 \\
\hline & & 3 & Andere rassen, dubbeldoelkoeien & 3,7 \\
\hline
\end{tabular}


Tabel B4.3 Resultaat expertworkshop voor bedrijfstype melkvee extensief.

\begin{tabular}{|c|c|c|c|c|}
\hline & Type maatregel & & Top vier meest gekozen maatregel & Score \\
\hline \multirow[t]{3}{*}{1} & Graslandbeheer & 1 & Graslandmengsels, kruidenrijk met vier soorten & 4,6 \\
\hline & & 2 & Graslandmengsels, doorzaai klaver & 4,5 \\
\hline & & 4 & Graslandmengsels, kruidenrijk met andere soorten & 3,5 \\
\hline \multirow[t]{2}{*}{2} & \multirow[t]{2}{*}{ Bouwplan en gewaskeuze } & 1 & Vergroten aandeel blijvend grasland in bouwplan & 4,4 \\
\hline & & 3 & Alternatieve voedergewassen telen (bijv. grasklaver, soja, bonen) & 3,0 \\
\hline \multirow[t]{3}{*}{3} & Bemesting & 1 & Verminderen gebruik kunstmest & 6,3 \\
\hline & & 2 & Optimalisatie dikke/dunne mest & 5,9 \\
\hline & & 3 & Precisiebemesting & 5,3 \\
\hline \multirow[t]{3}{*}{5} & Landschapselementen & 1 & Landschapselementen: lijn & 5,3 \\
\hline & & 2 & Randenbeheer, akkerranden & 3,7 \\
\hline & & 3 & Landschapselementen: punt & 2,6 \\
\hline \multirow[t]{3}{*}{6} & \multirow{3}{*}{$\begin{array}{l}\text { Locatiegebonden en } \\
\text { samenwerking }\end{array}$} & 1 & Samenwerking, veevoer van akkerbouwer & 5,1 \\
\hline & & 2 & Samenwerking, rotatie akkerbouw (grasland) & 4,1 \\
\hline & & 3 & Beperken transportafstanden veevoer & 2,4 \\
\hline \multirow[t]{3}{*}{7} & \multirow{3}{*}{$\begin{array}{l}\text { Stallen, mestopslag en } \\
\text { bewerking }\end{array}$} & 1 & Mest, scheiding & 7,1 \\
\hline & & 2 & Stal en opslag, emissiearm (RAV-lijst) & 4,4 \\
\hline & & 3 & Mest toedienen, emissiearm (grasland en bouwland) & 3,6 \\
\hline 9 & & 3 & Andere overeenkomsten agrarisch natuurbeheer & 2,6 \\
\hline \multirow[t]{3}{*}{10} & Diermanagement & 1 & Veestapel, vervangingspercentage verlagen, levensduur verhogen & 6,0 \\
\hline & & 2 & Fokkerij, weerstand koe verhogen & 4,8 \\
\hline & & 3 & Veestapel, antibioticagebruik verminderen & 2,3 \\
\hline
\end{tabular}


Tabel B4.4 Resultaat expertworkshop voor bedrijfstype akkerbouw op klei.

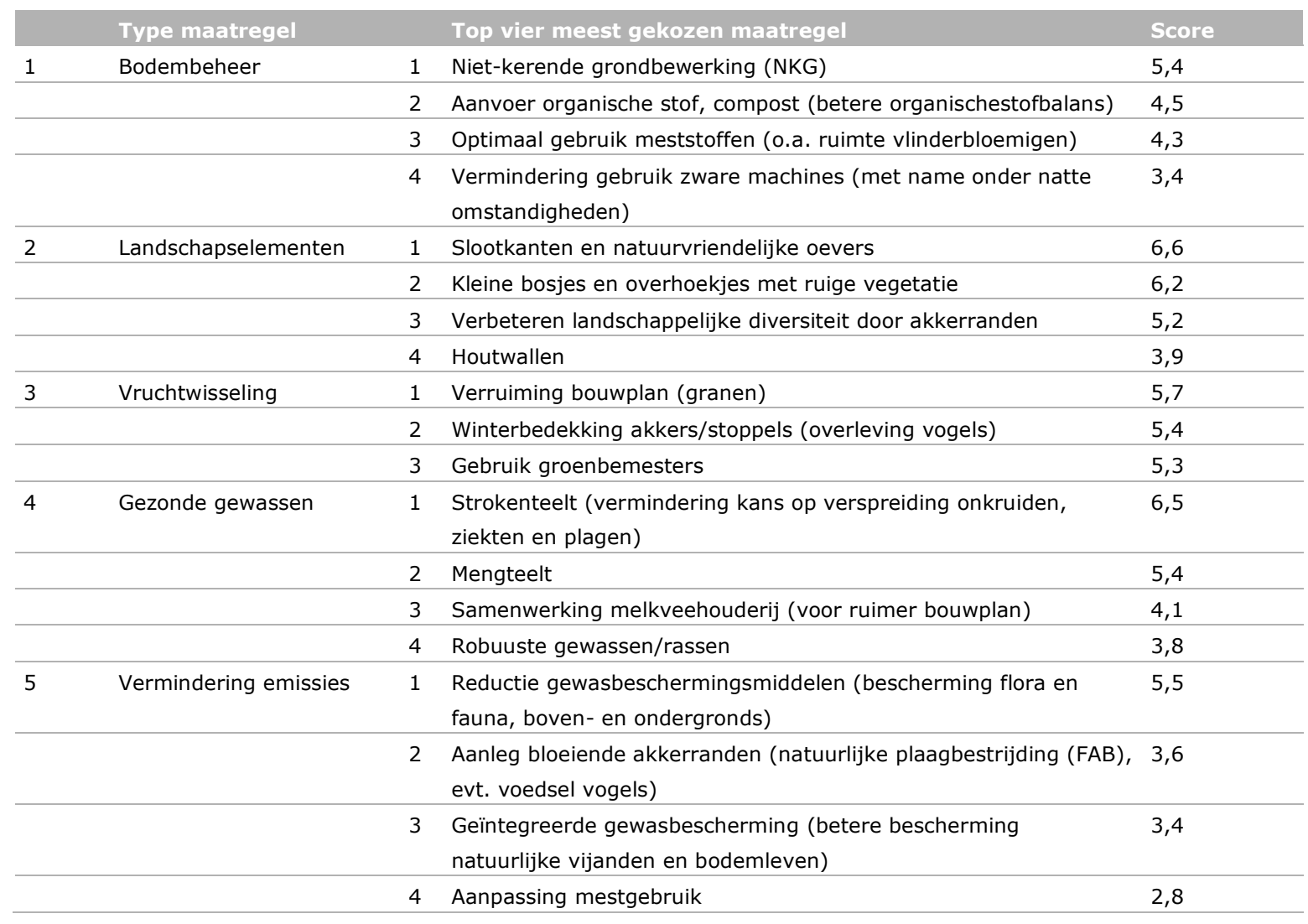


Tabel B4.5 Resultaat expertworkshop voor bedrijfstype akkerbouw op zand.

Dit bedrijfstype is niet op basis van de tool gescoord. In de discussie zijn verschillen met het kleibedrijf aangegeven. 
Wageningen Economic Research Postbus 29703

2502 LS Den Haag

T 0703358330

Ecommunications.ssg@wur.nl

Wageningen Economic Research RAPPORT

2019-105
De missie van Wageningen University \& Research is 'To explore the potential of nature to improve the quality of life'. Binnen Wageningen University \& Research bundelen Wageningen University en gespecialiseerde onderzoeksinstituten van Stichting Wageningen Research hun krachten om bij te dragen aan de oplossing van belangrijke vragen in het domein van gezonde voeding en leefomgeving. Met ongeveer 30 vestigingen, 5.000 medewerkers en 10.000 studenten behoort Wageningen University \& Research wereldwijd tot de aansprekende kennisinstellingen binnen haar domein. De integrale benadering van de vraagstukken en de samenwerking tussen verschillende disciplines vormen het hart van de unieke Wageningen aanpak. 



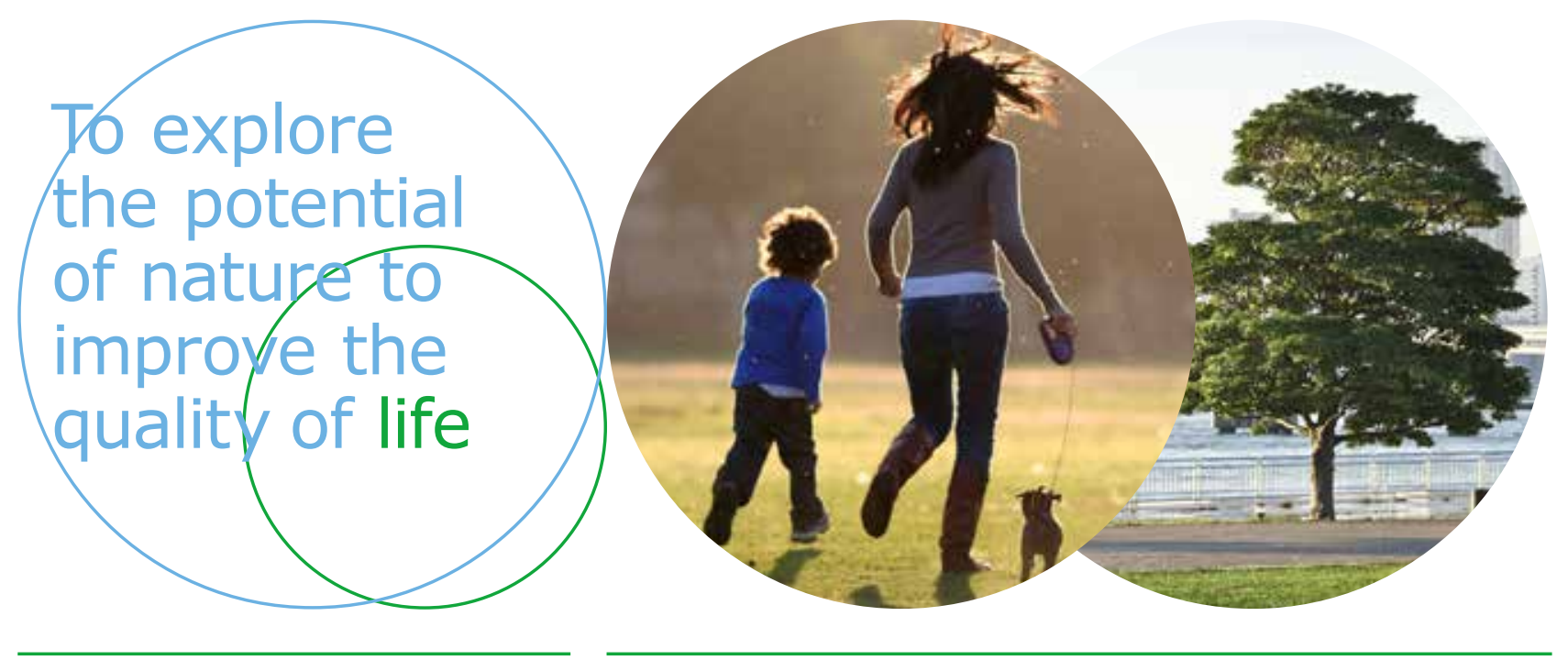

Wageningen Economic Research Postbus 29703

2502 LS Den Haag

E communications.ssg@wur.nl

$\mathrm{T}+31(0) 703358330$

www.wur.nl/economic-research

Report 2019-105

ISBN 978-94-6395-143-2
De missie van Wageningen University \& Research is 'To explore the potential of nature to improve the quality of life'. Binnen Wageningen University \& Research bundelen Wageningen University en gespecialiseerde onderzoeksinstituten van Stichting Wageningen Research hun krachten om bij te dragen aan de oplossing van belangrijke vragen in het domein van gezonde voeding en leefomgeving. Met ongeveer 30 vestigingen, 5.000 medewerkers en 10.000 studenten behoort Wageningen University \& Research wereldwijd tot de aansprekende kennisinstellingen binnen haar domein. De integrale benadering van de vraagstukken en de samenwerking tussen verschillende disciplines vormen het hart van de unieke Wageningen aanpak. 